\title{
WP/19/274
}

IMF Working Paper

What Is Real and What Is Not in the

Global FDI Network?

By Jannick Damgaard, Thomas Elkjaer, and

Niels Johannesen 


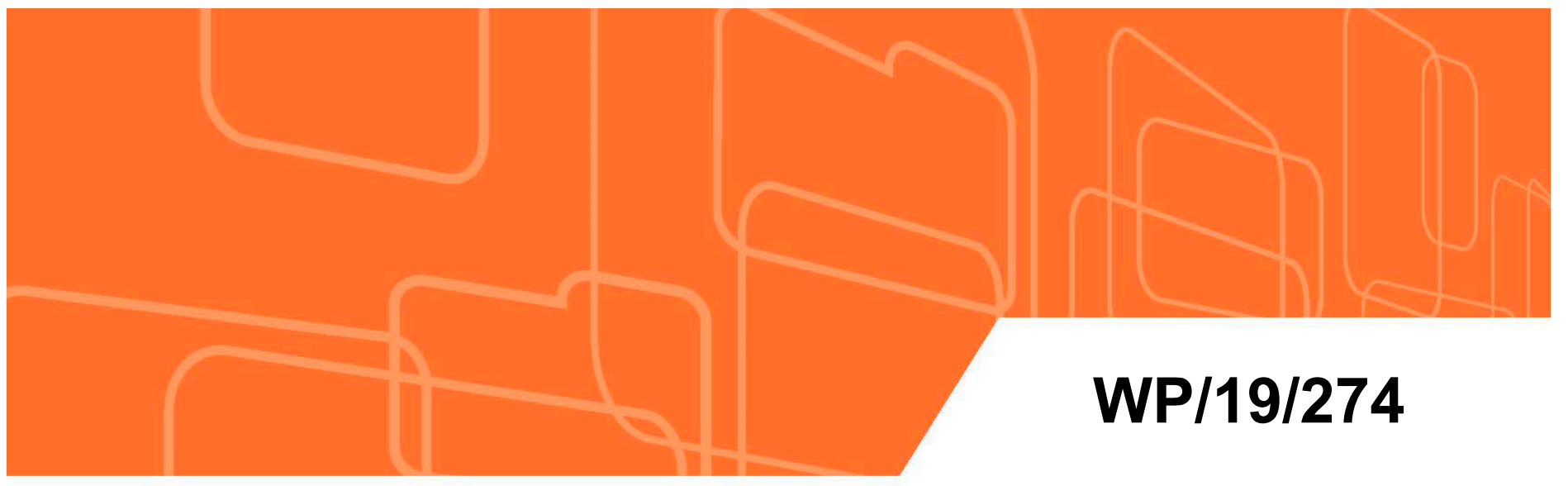

\title{
IMF Working Paper
}

\section{What Is Real and What Is Not in the Global FDI Network?}

\author{
By Jannick Damgaard, Thomas Elkjaer, and
}

Niels Johannesen 


\title{
IMF Working Paper
}

\author{
Statistics Department
}

What Is Real and What Is Not in the Global FDI Network?

Prepared by Jannick Damgaard, Thomas Elkjaer, and Niels Johannesen ${ }^{1}$

Authorized for distribution by Carlos Sánchez Muñoz

December 2019

\section{IMF Working Papers describe research in progress by the author(s) and are published to elicit comments and to encourage debate. The views expressed in IMF Working Papers are those of the author(s) and do not necessarily represent the views of the IMF, its Executive Board, or IMF management.}

\begin{abstract}
Macro statistics on foreign direct investment (FDI) are blurred by offshore centers with enormous inward and outward investment positions. This paper uses several new data sources, both macro and micro, to estimate the global FDI network while disentangling real investment and phantom investment and allocating real investment to ultimate investor economies. We find that phantom investment into corporate shells with no substance and no real links to the local economy may account for almost 40 percent of global FDI. Ignoring phantom investment and allocating real investment to ultimate investors increases the explanatory power of standard gravity variables by around 25 percent.
\end{abstract}

JEL Classification Numbers: F21, F23, F30

Keywords: Global FDI Network, Special Purpose Entities, Phantom FDI, Real FDI.

Authors’ E-Mail Addresses: jannick.damgaard@gmail.com; telkjaer@imf.org; niels.johannesen@econ.ku.dk

\footnotetext{
${ }^{1}$ We are grateful for constructive comments from colleagues at Danmarks Nationalbank and the IMF as well as JuanCarlos Suarez Serrato and other participants at the Academic Symposium on Business Taxation at Oxford University. We are also grateful for detailed feedback from the authorities of Belgium, Hong Kong SAR, Indonesia, Ireland, Luxembourg, Singapore, Switzerland and the United States. Niels Johannesen acknowledges support from the Danish National Research Foundation. The FDI data estimated in this paper, as well as code documenting the estimation from publicly available data sources, are available at https://nielsjohannesen.net/FDIdatabase/.
} 


\title{
What Is Real and What Is Not in the Global FDI Network?*
}

\author{
Jannick DAmGAARD (Danmarks Nationalbank) \\ Thomas ElkJAER (International Monetary Fund) \\ Niels JoHANneSEn (University of Copenhagen and CEBI)
}

December 2, 2019

\begin{abstract}
Macro statistics on foreign direct investment (FDI) are blurred by offshore centers with enormous inward and outward investment positions. This paper uses several new data sources, both macro and micro, to estimate the global FDI network while disentangling real investment and phantom investment and allocating real investment to ultimate investor economies. We find that phantom investment into corporate shells with no substance and no real links to the local economy may account for almost 40 percent of global FDI. Ignoring phantom investment and allocating real investment to ultimate investors increases the explanatory power of standard gravity variables by around 25 percent.
\end{abstract}

*We are grateful for constructive comments from colleagues at Danmarks Nationalbank and the IMF as well as Juan-Carlos Suarez Serrato and other participants at the Academic Symposium on Business Taxation at Oxford University. We are also grateful for detailed feedback from the authorities of Belgium, Hong Kong SAR, Indonesia, Ireland, Luxembourg, Singapore, Switzerland and the United Stated. Niels Johannesen acknowledges support from the Danish National Research Foundation. The FDI data estimated in this paper, as well as code documenting the estimation from publicly available data sources, are available at https://nielsjohannesen. net/FDIdatabase/. 


\section{Introduction}

Foreign direct investment (FDI) is an important dimension of international economic integration. It enters the most widely used indexes of globalization (Dreher, 2006) and attracting FDI is often an explicit policy objective because of its potential to boost productivity (Javorcik, 2004) and stimulate economic growth (Borensztein et al., 1998) through cross-border transfers of skills, technology and business practices.

However, not all FDI is about real economic integration. For instance, Luxembourg with little more than half a million inhabitants records an inward FDI position of around $\$ 4$ trillion, similar to the entire United States and much more than China. Investments of this magnitude hardly reflect productive assets employed in the small local economy. More likely, the bulk of the investments effectively pass through Luxembourg and into larger economies without leaving many real traces in the transit. Consistent with this explanation, Luxembourg records an outward FDI position that roughly matches the inward FDI position.

Figure 1 highlights that several small economies play an outsized role in the global FDI network: the Netherlands, Luxembourg, Hong Kong SAR, Switzerland, Singapore, Ireland, Bermuda, the British Virgin Islands and the Cayman Islands jointly host more than 40 percent of global FDI although their combined share of global GDP is only around 3 percent. Strikingly, these economies have tax systems that, in one way or another, are useful in the tax planning of multinational firms (e.g. Hines, 2010; Zucman, 2014). Tax planning is therefore a plausible explanation for the otherwise puzzling size of these FDI positions. Indeed, the concentration of holding and intra-group finance activities in favorable tax environments can lead to FDI positions that are entirely unrelated to the size of the local economy. ${ }^{1}$

While investments through offshore centers may have important adverse consequences for public finances in high-tax economies (Tørsløv et al., 2018), they also render standard FDI statistics much less useful for researchers and policymakers. First, FDI data becomes a noisy indicator of global economic integration: an increase in global FDI could reflect that real economic ties are deepening or that multinational firms are adding more layers of empty corporate shells to their ownership chains. Second, FDI data does not depict the true geography of global economic integration: the United Kingdom, for instance, records inward FDI of around \$160

\footnotetext{
${ }^{1}$ This is not a new proposition: already Hines and Rice (1994) highlight that U.S. firms allocate valuable assets but few productive resources, such as plant, property, equipment and employees, to "fiscal paradises." Other reasons than tax planning could also play a role. For instance, allocating financial assets and liabilities to Special Purpose Entities (SPEs) in offshore centers may move risk away from the parent company's balance sheet. SPEs may also provide increased confidentiality as disclosure requirements for such entities are typically low, or they could more generally be utilized to take advantage of differences in regulatory environments.
} 
billion from Luxembourg and while it is clear that the vast majority derives from ultimate investors in other economies (or in the United Kingdom itself), standard statistics offer no way to quantify these investment ties.

The main aim of this paper is to estimate the global network of FDI positions while disentangling what we consider Real FDI, the relation between an investor in one economy and an active and substantial business in another economy, and what we consider Phantom FDI, investments into empty corporate shells with no link to the local real economy.

Our point of departure is standard FDI statistics indicating for each economy its inward FDI position by the economy of the immediate investor. Around 110-115 economies currently report such information to the IMF's Coordinated Direct Investment Survey (CDIS) based on annual surveys where a large number of businesses are asked about their foreign investors and foreign investments. FDI statistics are intended to capture long-term strategic investment relationships; however, in practice, FDI encompasses all cross-border financial investments between firms belonging to the same multinational group (OECD, 2008; IMF, 2009). The statistical offices aggregate individual cross-border equity and debt positions to FDI positions. The positions are expressed in stocks, the estimated market value of the business interests at the time of the survey, by economy of the immediate investor, which need not coincide with the economy of the ultimate investor.

The first step is to complete the global FDI network to the greatest extent possible based on information from CDIS. When information on inward FDI is directly reported, we retain it: France records inward FDI from Canada of around $\$ 3.8$ billion and we adopt this number directly. When information on inward FDI is not available, which is notably the case for many important offshore centers, we provide estimates based on mirror data: the Cayman Islands does not report inward FDI from Canada (or any other economies); however, Canada reports outward FDI to the the Cayman Islands of around $\$ 34$ billion and we use this number as an estimate of inward FDI into the Cayman Islands from Canada.

Next, we split the inward FDI position of each economy into Real FDI and Phantom FDI. We utilize new data from a group of OECD countries that have recently started reporting inward FDI separately for the subset of domestic firms with few or no employees, little or no production, little or no physical presence and no other activities than holding and financing. Investment into such Special Purpose Entities (SPEs) corresponds closely to our concept of Phantom FDI. For this group of economies, we simply adopt the self-reported statistics on inward FDI into SPEs and non-SPEs as measures of Phantom FDI and Real FDI respectively. 
For the remaining economies, we need to estimate the decomposition of Total FDI into Real FDI and Phantom FDI. We exploit a salient pattern within the group of economies self-reporting Real FDI and Phantom FDI: the ratio of Real FDI to Total FDI exhibits a strong and robust negative correlation with the ratio of Total FDI to GDP. For instance, Sweden with Total FDI at around 0.7 times GDP reports that Real FDI accounts for around 95 percent of Total FDI whereas Luxembourg with Total FDI exceeding 60 times GDP reports that Real FDI accounts for less than 5 percent of Total FDI. More generally, a 1 percent increase in the ratio of Total FDI to GDP is associated with a 0.5 percent decrease in the ratio of Real FDI to Total FDI. ${ }^{2}$ Presumably, this correlation reflects that there is a structural limit to the amount of Real FDI an economy can absorb whereas Phantom FDI can grow without bound exactly because it is not real. Hence, in economies where the ratio of Total FDI to GDP is many times larger than usual, most FDI is likely to be Phantom FDI. From the estimated relation between the share of Real FDI in Total FDI and the ratio of Total FDI to GDP in the sample of economies where Real FDI is self-reported, we predict the share of Real FDI in Total FDI for all the economies where Real FDI is not self-reported. Consistent with intuition, we find that Real FDI accounts for the entire inward FDI position in most OECD economies but only for a tiny fraction in economies like Gibraltar, Bermuda and the Cayman Islands.

Finally, for each economy in the world we assign Real FDI to the economies of the ultimate investors. We exploit two data sources. First, a group of OECD economies have recently added questions about the ultimate investor economy to the surveys underlying the FDI statistics: the surveyed firms are asked to go through the chain of controlling owners until they identify a firm that is not controlled by any other firm. The economy of this ultimate owner is the ultimate investor economy. For this sample of economies, we simply adopt the self-reported statistics on FDI by ultimate investor economy. Second, for the remaining economies, we use corporation-level balance sheets and ownership links from the leading firm database Orbis to estimate conversion factors that translate Real FDI by immediate owners in a counterpart economy into Real FDI by ultimate owners in the same counterpart economy. An example illustrates the basic principles: Spain's Real FDI from immediate owners in the United States is $\$ 23$ billion. In Orbis, we observe investments in Spain owned by immediate investors in the United States for $\$ 13$ billion and investments in Spain owned by ultimate investors in the United States for $\$ 29$ billion. Hence, we obtain a conversion factor of 2.2 (i.e. $\$ 29$ billion $/ \$ 13$ billion) and an estimate of Real FDI in Spain from ultimate owners in the United States of just over $\$ 50$

\footnotetext{
${ }^{2}$ We show that this correlation barely changes when controlling for economy size, income level and trade openness separately or jointly.
} 
billion (i.e. $\$ 23$ billion*2.2). We only use this approach when Orbis covers a large fraction of FDI so that the ownership links observed in the database can be assumed to be representative of the full population of firms.

We obtain three sets of results from our new database. The first concerns the level, the distribution and the trends in Phantom FDI. While Total FDI stood at almost $\$ 40$ trillion globally in 2017, around $\$ 15$ trillion of these investments were, according to our estimates, phantom investments into empty shell corporations with no real activities. The share of Phantom FDI in Total FDI has been growing steadily in the past years from slightly above 30 percent in 2009 to almost 40 percent in 2017. ${ }^{3}$ Most Phantom FDI is hosted by economies known to play an important role in the tax planning of multinational firms (e.g. Hines, 2010; Zucman, 2014): in both Luxembourg and the Netherlands Phantom FDI stands at more than $\$ 3$ trillion whereas Hong Kong SAR, the British Virgin Islands, Bermuda, Singapore, the Cayman Islands and Ireland each account for $\$ 0.5-1$ trillion. We show that these patterns are robust to a number of methodological choices. ${ }^{4}$

The next set of results concerns the real FDI network: the links from ultimate investors to investments in corporations with real activities. We estimate that global Real FDI stood at around $\$ 25$ trillion in 2017. Real bilateral investment links between the largest economies, like United States, China, United Kingdom, Germany and France, are much stronger than investment links in standard FDI statistics where real and phantom investment are conflated. To illustrate, we estimate that moving from standard FDI statistics to our estimates of real investment links increases the combined explanatory power of gravity variables like GDP and distance by around 25 percent.

The final set of results quantifies the exposure of individual economies to Phantom FDI. Channeling foreign investment through low-tax economies provides firms with a range of tax avoidance opportunities, both in the economy that is home to the ultimate investor and in the economy hosting the real investment. While it is beyond the scope of this study to determine to what extent firms make use of these opportunities, the share of an economy's inward FDI coming from empty shells and the share of its outward FDI going to empty shells provide summary measures of exposure. We find that exposure to Phantom FDI, notably among low-

\footnotetext{
${ }^{3}$ Incidentally, a recent influential study estimates that a similar share, around 40 percent, of the profits earned by multinational firms outside of their home economy is booked in low-tax economies (Tørsløv et al., 2018).

${ }^{4}$ Global Phantom FDI still stands at around $\$ 7.4$ trillion under the extreme assumption that Phantom FDI is zero in all the economies that do not themselves report statistics on foreign investment into SPEs, which implies that all inward FDI in Hong Kong SAR, the British Virgin Islands, Bermuda, the Cayman Islands, Singapore and other offshore financial centers would be into corporations with real activities in the local economy.
} 
income economies, correlates positively with the corporate tax rate, which is consistent with the notion that some Phantom FDI serves tax avoidance purposes. ${ }^{5}$

The key contribution of our paper is to combine new data sources, both macro and micro, to make a systematic attempt at disentangling the FDI that represents real economic links and the FDI that does not. ${ }^{6}$ This is important from the vantage point of the vast empirical literature that is concerned with the causes (e.g. Hines, 1996; Harding and Javorcik, 2011; Javorcik et al., 2011) and consequences (e.g. Alfaro et al., 2004; Harding and Javorcik, 2012; Javorcik and Poelhekke, 2017) of firm investment across borders. Since the research questions underlying most of these papers relate directly to Real FDI, standard FDI data with a large share of Phantom FDI, which is certainly not randomly distributed across economies, may give rise to significant biases. Our new database is publicly available to allow others to use our estimates of real cross-border investment links in their own research.

Our analysis also contributes to a large literature in public finance documenting how multinational firms allocate a disproportionate share of their financial assets (Clifford, 2019), intangible assets (Dischinger and Riedel, 2011), patents (Karkinsky and Riedel, 2012; Griffith et al, 2014) and business risks (Becker et al., 2018) to low-tax environments. While most of this literature uses micro-data and carefully estimates how elastic firms' choices are with respect to corporate tax differentials, our analysis offers a complementary macro-perspective with estimates of phantom investment at the level of individual economies and the world as a whole. Most similar in spirit is a recent paper that uses national accounts data to estimate the global distribution of firms' foreign profits (Tørsløv et al., 2018). ${ }^{7}$ Based on the premise that a significant share of Phantom FDI is tax motivated, our methodology offers a quantitative approach to assessing the progress in the policy effort against tax avoidance at the global level (OECD, 2019) and to identify individual economies that are central to firms' tax avoidance strategies.

The paper proceeds in the following way. Section 2 documents the estimation of a new global database on FDI. Section 3 illustrates key characteristics of the FDI network and reports various sensitivity tests. Section 4 concludes.

\footnotetext{
${ }^{5}$ This is consistent with evidence that profit shifting responds more strongly to tax incentives in low-income economies where anti-avoidance rules are less developed and tax enforcement is weaker (Johannesen et al., 2016).

${ }^{6}$ This paper supersedes Damgaard and Elkjaer (2017) who disentangle Phantom FDI and Real FDI for a single year and a smaller set of economies and assign Real FDI to ultimate investor economies using reported FDI data.

${ }^{7}$ There is also a small related literature on the geography of FDI in offshore financial centers (Haberly and Wójcik, 2015; Garcia-Bernardo et al., 2017).
} 


\section{Estimating the global FDI network}

This section documents the estimation of a new global database on FDI with four key statistics for each pair of economies: Total FDI in host economy $h$ by immediate investors in economy $i$; Phantom FDI in host economy $h$ by immediate investors in economy $i$; Real FDI in host economy $h$ by immediate investors in economy $i$; and Real FDI in economy $h$ by ultimate owners in economy $i$. The database is internally consistent by construction: for any pair of economies Real FDI and Phantom FDI sum to Total FDI, and for any economy Real FDI across immediate owners sums to Real FDI from ultimate owners. ${ }^{8}$

\subsection{Data sources}

The IMF's CDIS is the most comprehensive source of information on FDI positions. The survey is currently conducted annually in 110-115 economies, including all major economies in the world, under the auspices of the IMF's Statistics Department. In each of the participating economies, national authorities combine administrative data and survey information about foreign investors and foreign investments from local firms. The survey process follows detailed guidelines based on international macroeconomic statistical manuals to ensure consistent definitions and similar data collection practices across the participating economies. The local authorities aggregate the survey information to produce estimates of inward FDI by the economy of the immediate investor and outward FDI by the economy of the immediate investment. ${ }^{9}$

The OECD FDI Statistics include additional information on FDI positions for a smaller group of OECD economies. First, 30 economies specify how much inward FDI is into SPEs and how much is into other entities (non-SPEs). The statistical manuals describe an SPE as a formally registered legal entity subject to national law that satisfies several criteria: it has few or no employees; it has little or no production in the host economy; it has little or no physical presence; its ultimate owners are foreign residents; its assets and liabilities are mostly vis-a-vis non-residents; and its core business consists of group financing or holding activities (OECD, 2008). ${ }^{10}$ FDI into SPEs falls within the standard definition of FDI and is generally included in the FDI reported to CDIS. However, since it has no real economic significance for the host

\footnotetext{
${ }^{8}$ The database itself as well as the Stata code documenting how it is built from publicly available data sources are available at https://nielsjohannesen.net/FDIdatabase/.

${ }^{9}$ The data is available at http://data.imf .org/CDIS.

${ }^{10}$ To improve the availability of greater information on SPEs, the IMF's Statistics Department is promoting international convergence towards an internationally agreed definition of SPEs and the launch of an annual international data collection to allow separate identification of cross-border transactions and positions of SPEs, with data for 2020 to be collected in 2021.
} 
economy, we label it Phantom FDI as opposed to foreign investment into non-SPEs, which we label Real FDI. This decomposition yields a conservative estimate of Phantom FDI as foreignowned corporations with mixed activities, e.g. production to the local market and passive shareholdings in foreign subsidiaries, are classified as non-SPEs, implying that all the foreign investment they embody is classified as Real FDI. ${ }^{11}$ Second, 16 economies provide information on inward FDI by the economy of the ultimate owner. The ultimate owner is identified by starting from the immediate owner and moving up the ownership chain through the controlling links. The first enterprise in the chain that is not itself controlled by another enterprise (e.g. because it is a listed firm with no single shareholder owning more than 50 percent) is the ultimate owner. If the immediate owner is not controlled by another enterprise, it is itself the ultimate owner.

We summarize the three FDI data sources and their coverage in 2016 in Table 1. ${ }^{12}$ Aggregate inward FDI across the 111 economies reporting to the CDIS was just above $\$ 30$ trillion, of which around 95 percent was allocated to immediate investor economies. The 16 economies reporting (non-zero) inward FDI in SPEs and non-SPEs separately account for almost 40 percent of the total inward FDI in CDIS whereas the 12 economies further allocating inward Real FDI to ultimate investor economies account for around 20 percent.

Finally, the global firm database Orbis includes accounting and ownership information for millions of corporate entities at the unconsolidated level. To be concrete, consider a multinational group comprising a listed parent company in Canada, an intermediate holding company in Luxembourg and an operating subsidiary in Spain. In this example, we would observe a balance sheet and background information such as the number of employees for each of the three entities. We would also observe the ownership links between them. For the Spanish entity, the database would indicate that the immediate owner is the Luxembourg company and the ultimate owner is the Canadian company (both with a 100 percent shareholding). For the Luxembourg company, it would indicate that the Canadian company is both the immediate and the ultimate owner (with a 100 percent shareholding).

We use the information from Orbis to produce estimates of FDI by ultimate investor economy

\footnotetext{
${ }^{11}$ The international statistical community has recently proposed a definition of SPEs where all entities with more than five employees would be classified as non-SPEs regardless of the size of the balance sheet (IMF, 2018). The Netherlands has implemented this new definition, which led to a reclassification of 250 businesses that combine a channeling function with some degree of non-financial productive activities. This reclassification moved $\$ 750$ billion of inward FDI, corresponding to around 90 percent of Dutch GDP, from SPEs to non-SPEs. As the reclassification is only reflected in reported data from 2015 onwards, we have implemented the revision going back to 2009 to avoid a break in the data series.

${ }^{12}$ Data coverage varies somewhat across years.
} 
for economies that do not report such statistics directly. ${ }^{13}$ Intuitively, the concrete example above would suggest that inward FDI in Spain by immediate investors in Canada should be adjusted upwards to arrive at FDI in Spain by ultimate investors in Canada; conversely, FDI in Spain by immediate investors in Luxembourg should be adjusted downwards to arrive at FDI in Spain by ultimate investors in Luxembourg. A key constraint is Orbis' partial coverage (e.g. Tørsløv et al., 2018): in any given economy only a subset of corporations are represented in the database, and coverage varies considerably across economies and over time. Importantly, we do not attempt to capture levels of FDI with the Orbis data and therefore do not assume that coverage is complete. Rather we use Orbis to measure the ratio between FDI by immediate and ultimate investors in a given economy and thus assume that the ownership patterns observed in the Orbis sample are representative of the wider economy. For this reason, we only rely on Orbis data for pairs of economies where a large part of the bilateral FDI (at least 50 percent) is represented in the database.

\subsection{Total FDI by economy of immediate investor}

We first estimate the bilateral positions of Total FDI: the direct investment in host economy $h$ by immediate investors in economy $i$. The estimated network includes all 246 economies in the world and covers the period 2009-2017.

For the 110-115 economies reporting inward FDI positions to the CDIS, we use these reports without any adjustment. For instance, France reports inward FDI from Canada of around $\$ 3.8$ billion in 2017 and this figure enters our database directly. For the 130-135 economies not reporting to the CDIS, mostly small developing economies and offshore financial centers, we estimate FDI positions based on mirror data. For instance, the Cayman Islands does not report inward FDI from Canada; however, Canada reports outward FDI to the Cayman Islands of around $\$ 34$ billion and we use this number as an estimate of inward FDI into the Cayman Islands from Canada. ${ }^{14}$

Since mirror positions are only available for counterpart economies reporting to the CDIS, we would systematically underestimate economy-level inward FDI for non-reporting economies

\footnotetext{
${ }^{13}$ The Orbis database has been used extensively in the literature on international taxation to document how multinational firms allocate assets (Clifford, 2019), liabilities (Huizinga et al., 2008), profits (Huizinga and Laeven, 2008; Johannesen et al, 2016) and risk (Becker et al., 2018) across affiliates in response to tax incentives.

${ }^{14}$ Damgaard and Elkjaer (2017) find that while there can be significant asymmetries in reported mirror data, there is no systematic overstatement of inward FDI compared to outward FDI, or vice versa. However, data on inward FDI is generally of better quality than on outward FDI as it is easier to obtain information about resident than non-resident firms engaged in FDI from business registers, particularly when they are not listed. For this reason, we use reported inward FDI as our main data source.
} 
if we only relied on mirror positions. For instance, when we estimate the inward FDI position of the Cayman Islands against the rest of the world in 2017, we can only create mirror estimates for 53 economies; the subset of the economies participating in the CDIS that report their outward FDI position to the Cayman Islands. The simple sum of these mirror estimates, $\$ 611$ billion, almost certainly underestimates the sum of all inward FDI to the Cayman Islands from the 246 economies in the world.

We address this gap by applying an adjustment factor to the sum of the mirror estimates when we compute economy-level FDI positions for non-reporting economies. The adjustment factor is computed as the ratio between reported inward FDI positions and the sum of mirror positions for the set of economies $\mathbb{R}$ reporting inward FDI:

$$
\alpha_{t}^{\text {mirror }}=\frac{\sum_{h \in \mathbb{R}} \text { Inward FDI } I_{h i, t}^{\text {reported }}}{\sum_{i \in \mathbb{R}} \text { Outward FDI } I_{i h, t}^{\text {reported }}}
$$

where InwardFDI $I_{h i, t}^{\text {reported }}$ is inward FDI in $h$ from $i$ as reported by $h$ and OutwardFDI $I_{i h, t}^{\text {reported }}$ is outward FDI from $i$ to $h$ as reported by $i$. The adjustment factor in 2017 is 1.17 suggesting that, for the aggregate of reporting economies, actual total inward FDI is 17 percent higher than the sum of the mirror positions. We assume that the same is true for each of the non-reporting economies. For the Cayman Islands, this implies that we estimate economy-level inward FDI at $\$ 712$ billion ( $\$ 611$ billion * 1.17). We are unable to allocate the adjustment $\$ 101$ billion ( $\$ 611$ billion * 0.17$)$ to any specific counterpart economy and therefore allocate to the category "Not specified."

We compute the adjustment factor for each year in the sample period separately; the adjustments are in the range 1.15-1.25 in every year. We emphasize that aggregate adjustments only account for around 1.5 percent of global FDI because the largest recipients of FDI tend to report to CDIS and the adjustments only apply to non-reporting economies.

\subsection{Decomposition: Real vs Phantom investment}

In the next step, we decompose each inward FDI position into Real FDI and Phantom FDI. For the sample of OECD countries reporting by counterpart economy how much inward FDI is into SPEs and non-SPEs respectively, we use this information directly. ${ }^{15}$ For instance, the Netherlands reports inward FDI from the United States of around $\$ 750$ billion in SPEs and of around

\footnotetext{
${ }^{15}$ However, if aggregate inward FDI reported to the OECD FDI Statistics deviates by more than 20 percent from the CDIS, e.g. due to large revisions or different valuation methods, we only use the overall breakdown into SPEs and non-SPEs.
} 
\$200 billion in non-SPEs in 2017; these figures enter our database as estimates of Phantom FDI and Real FDI without any adjustments. For the sample of OECD countries specifying the decomposition on SPEs and non-SPEs only in the aggregate, we assume that the decomposition is the same for all counterpart economies. For instance, Luxembourg reports aggregate inward FDI of $\$ 3,800$ billion in SPEs and less than $\$ 200$ billion in non-SPEs, implying that Real FDI and Phantom FDI account for around 4 percent and 96 percent of Total FDI respectively in the aggregate. To estimate Real FDI and Phantom FDI at the bilateral level, we assume that these shares apply uniformly to all counterpart economies. For instance, Luxembourg reports Total FDI from Canada of $\$ 194$ billion and we thus estimate that Real FDI from Canada is $\$ 9$ billion ( $\$ 194$ billion * 0.04) whereas Phantom FDI is $\$ 185$ billion ( $\$ 194$ billion * 0.96).

While 30 OECD economies provide information about FDI into SPEs and non-SPEs, around half of these economies simply report that there is no FDI into SPEs. Most notably, this is the case for the United States despite evidence that the state of Delaware is a leading jurisdiction for incorporation of empty shells. It hosts more than 1 million business entities (Delaware Division of Corporations) that serve the tax planning purposes of U.S. as well as non-U.S. firms (Dyreng et al, 2013). ${ }^{16}$ To understand the nature of these reports, we have conducted a survey among the divisions of statistical agencies responsible for FDI statistics. The survey responses indicate that FDI into SPEs are not literally zero even when this is reported in the new FDI statistics. Instead, it often indicates that the information is not collected. Given the uncertainty about how to interpret such observations, we recode them to missing in the main analysis and only retain the reported decomposition of FDI into SPEs and non-SPEs for the 16 economies that report a value of FDI into SPEs different from zero. The 16 economies include some of the world's most important financial centers (e.g. the Netherlands and Luxembourg), advanced economies (e.g. Norway and Spain) and emerging markets (e.g. Poland and Chile), and the sample therefore represents a broad subset of the global economy.

Based on the information from the 16 economies reporting an actual breakdown of Total FDI into Real FDI and Phantom FDI, we estimate a similar decomposition for the remaining economies in the world. The estimation exploits a highly salient correlation within the sample of reporting economies between the ratio of Real to Total FDI and the ratio of Total FDI to GDP. For instance, Sweden where Total FDI stands at around 0.7 times GDP, reports that Real FDI accounts for around 95 percent of Total FDI whereas Luxembourg with Total FDI

\footnotetext{
${ }^{16}$ A recent micro-analysis (Noonan, 2019) suggests that the United States is used as a destination for passthrough capital to a limited extent. According to the Bureau of Economic Analysis, much of the investment in Delaware from foreign parents passes on to operating affiliates in the United States.
} 
exceeding 60 times GDP, reports that Real FDI accounts for less than 5 percent of Total FDI. There are strong economic reasons to expect this relation to hold more broadly. While the capacity to absorb real investment into firms with employees and productive assets is limited, there are no economic bounds on phantom investment into empty corporate shells with no ties to the local economy. When the Total FDI position is unusually large relative to the size of the economy, it is therefore reasonable to expect that a smaller share of the FDI is real. Our approach is thus to extrapolate the relationship between the ratio of Real FDI to Total FDI, which is unobserved except for the 16 reporting economies, and the ratio of Total FDI to GDP, which can be calculated for virtually all economies in the world.

We first estimate the following univariate model for the 16 reporting economies and the period 2013-2017:

$$
\log \left(\frac{\operatorname{RealF} D I_{h t}}{\operatorname{TotalF} D I_{h t}}\right)=\alpha+\beta \log \left(\frac{\text { TotalFDI }}{G D P_{h t}}\right)+\epsilon_{h t}
$$

where Real FDI $I_{h t}$ is inward FDI in non-SPEs in economy $h$ in year $t$; Total FDI $I_{h t}$ is all inward FDI in economy $h$ in year $t$; and GDP is the Gross Domestic Product in economy $h$ in year $t .^{17}$

Figure 2 (upper panel) illustrates the estimated log-log relation: the estimated slope is around -0.5 suggesting that increasing the ratio of Total FDI to GDP by 1 percent reduces the predicted ratio of Real FDI to Total FDI by around 0.5 percent. The figure highlights the three economies in the sample, which consistently have a low ratio of Real FDI to Total FDI through the sample period: Luxembourg (red), Netherlands (blue) and Hungary (green). The $R^{2}$ of the model is 0.84 .

Next, we use the estimated coefficients from Equation (2) to predict the ratio of Real to Total FDI for all other economies in the world. Figure 2 (lower panel) shows the actual ratios of Real FDI to Total FDI for the 16 reporting economies (green) and predicted ratios for the remaining economies (blue), plotted against the ratio of Total FDI to GDP. ${ }^{18}$ The figure highlights that the univariate model fits the observations for the reporting economies well and illustrates the implied functional form: the ratio of Real FDI to Total FDI approaches zero as Total FDI to GDP approaches infinity. The predicted ratio of Real FDI to Total FDI is lowest for tiny offshore centers such as the Cayman Islands, Bermuda and Gibraltar.

\footnotetext{
${ }^{17}$ The model allows for the possibility that offshore financial centers with high ratios of Total FDI to GDP may have high ratios of both Phantom FDI and Real FDI to GDP reflecting that they receive significant pass-through FDI but at the same time may receive significant FDI into entities with real economic functions such as regional headquarters.

${ }^{18}$ When the model implies that Real FDI accounts for more than Total FDI, we bound this share at unity.
} 
We probe the robustness of the estimation results in several ways. First, one may be concerned that the strong correlation in the univariate model is spurious and reflects a correlation between the dependent variable and variables outside the model. We document that adding controls has remarkably little influence on the estimates. As shown in Table 2, the coefficient on the ratio of Total FDI to GDP barely changes when the model is augmented with variables capturing market size (Column 2), economic development (Column 3) and openness (Column 4). This suggests that the strong correlation in the univariate model reflects a genuine economic mechanism that can be expected to hold beyond the economies in the estimating sample. Second, the small estimating sample raises the concern that the results are sensitive to observations from a single economy. We address this concern by conducting a simple exercise where we re-estimate the univariate model removing one economy at a time from the estimating sample. Figure 3 (upper panel) illustrates the 16 regression lines while highlighting the estimates that result from omitting each of the three outliers, Hungary, the Netherlands and Luxembourg. The results are almost indistinguishable across samples except that the regression line becomes noticeably flatter when Luxembourg is omitted. This suggests that extrapolating from the baseline results may be misleading if Luxembourg has a markedly different ratio of Real FDI to Total FDI than other economies with a similar ratio of Total FDI to GDP. Third, the baseline model pools the years 2013-2017, which could potentially conceal large differences across years. Figure 3 (lower panel) shows the five regression lines resulting from estimating the baseline model for each of the years separately. The estimates are virtually identical across the period 2013-2016 and only slightly different for 2017 suggesting that the estimated relation is stable over time.

Figure 4 (upper panel) summarizes the sensitivity analysis by plotting the baseline predictions against the predictions that result from augmenting the model with a full set of controls (blue), excluding observations for Luxembourg (red) and using only observations from 2017 (green). Adding controls occasionally changes the ranking of economies with a similar ratio of Total FDI to GDP relative to the baseline, but does not systematically change the predicted ratio of Real FDI to Total FDI across the distribution. Excluding observations for Luxembourg (mechanically) retains the ranking of economies, but raises (lowers) the predicted ratio of Real FDI to Total FDI for economies with high (low) ratios of Total FDI to GDP. Relying only on observations from 2017 has the opposite effect although somewhat less pronounced: it slightly lowers (raises) the predicted ratio of Real FDI to Total FDI for economies with a high (low) ratio of Total FDI to GDP.

Finally, we use the baseline predictions to decompose inward FDI positions into Real FDI 
and Phantom FDI for economies where this decomposition is not directly available in reported statistics. For a given economy, we apply the same prediction uniformly to all counterpart economies. For instance, we predict that Total FDI into the Cayman Islands is 95 percent Phantom FDI and 5 percent Real FDI. Applying these shares to our estimate of Total FDI into the Cayman Islands from Canada of $\$ 34$ billion, we set Phantom FDI at $\$ 32.5$ billion and Real FDI at $\$ 1.5$ billion. Applying the same ratios to FDI into the Cayman Islands from other economies, we decompose the entire inward FDI position of the Cayman Islands. We proceed similarly to decompose the inward FDI positions of other economies. ${ }^{19}$ When no information on GDP is available, we are unable to calculate the ratio of Total FDI to GDP and therefore cannot predict the ratio of Real to Total FDI. In these rare cases, we apply the ratio corresponding to the simple average across the reporting OECD economies (i.e. 78 percent of Total FDI is Real FDI). Figure 4 (lower panel) shows the estimated share of Real FDI in Total FDI for all economies where this share is not unity. We distinguish between a broad set of offshore financial centers (red bars) and other economies (blue bars). ${ }^{20}$ Strikingly, almost all the economies with the lowest ratio are offshore financial centers and largely overlap with the list of sink and conduit offshore financial centers identified in Garcia-Bernardo et al. (2017) although the methodologies are quite different.

\subsection{Real FDI by economy of ultimate investor}

The final step in the estimation of the FDI database is to break down inward Real FDI by the economy of the ultimate investors. This completes the attempt to look through chains of Phantom FDI and capture the genuine cross-border investment links: from real investment in productive assets in one economy to the investors who ultimately control the assets in another economy.

\subsubsection{FDI statistics by economy of ultimate investor}

For the sample of OECD countries reporting Real FDI by the economy of the ultimate investor, we generally use this information directly. For instance, Germany reports inward FDI of $\$ 51$ billion from ultimate owners in Luxembourg in 2016. This compares to $\$ 143$ billion of inward FDI from immediate owners in Luxembourg reported to the CDIS and thus suggests that significant foreign investment into Germany is channeled through Luxembourg by firms in third

\footnotetext{
${ }^{19}$ Figure A3 in the Online Appendix empirically assesses the assumption of uniform ratios across counterpart economies for the sample of economies where ratios are reported for each counterpart economy separately.

${ }^{20}$ The set of offshore financial centers is from Johannesen and Zucman (2014) augmented with the Netherlands (Weyzig, 2013) and Puerto Rico (Grubert and Slemrod, 1998).
} 
economies. In the few cases where the reported FDI positions by ultimate investor economies are incomplete or inconsistent with the FDI positions by immediate investor economies reported to the CDIS, we ignore them and proceed as if no breakdown by ultimate investor economy were available. ${ }^{21}$ The reporting of FDI by ultimate investor economy started in 2013, so our global FDI network only covers this dimension for the period 2013-2017.

\subsubsection{Orbis database}

For all other economies, we start from the estimates of Real FDI by immediate investor economy obtained in the previous step and apply a conversion factor $\delta_{h i}$ obtained from the global firm database Orbis. $^{22}$ The conversion factor expresses, for a given host economy $h$ and a given investor economy $i$, the estimated ratio between real investment in $h$ by ultimate investors in $i$ and real investment in $h$ by immediate investors in $i$. Intuitively, the conversion factor captures how much a given counterpart economy is used as a conduit for investments originating from other economies (which decreases $\delta_{h i}$ ) relative to how much it uses other economies as conduits for its own foreign investments (which increases $\delta_{h i}$ ). With these conversion factors, Real FDI by ultimate investor economy follows from the following simple formula:

$$
\text { Real FDI } I_{h i}^{U I E}=\delta_{h i} \text { Real FDI } I_{h i}^{I I E}
$$

To estimate the conversion factors, we rely on information from Orbis. For each corporation in the database owned by foreign investors, we first approximate the value of the investment and then aggregate to obtain economy-level measures of FDI by immediate and ultimate investor economy.

First, we construct the sample of corporate entities in Orbis receiving Real FDI. Specifically, we extract accounting and ownership information for all corporations where at least one immediate investor with an ownership share of at least 10 percent is located in a foreign economy. The 10 percent threshold is conventionally used to delineate direct investment and portfolio investment in external statistics. To focus on Real FDI, we drop corporations with characteristics resembling SPEs: at most five employees and assets per employee exceeding $\$ 10$ million. $^{23}$

\footnotetext{
${ }^{21}$ Specifically, we ignore the breakdown on ultimate investor economies reported to the OECD in two instances: (i) when less than 50 percent of Real FDI is allocated to specific ultimate investor economies; (ii) when the discrepancy between FDI positions by ultimate investor economy aggregated across all counterpart economies and FDI positions by immediate investor economy aggregated across all counterpart economies exceeds 20 percent.

${ }^{22}$ The present study is the first to use micro data to allocate FDI by ultimate investor economy. A previous version (i.e. Damgaard and Elkjaer, 2017) used aggregate investment patterns from reporting OECD countries whereas Casella (2019) takes a probabilistic approach.

${ }^{23}$ With this definition, around 8 percent of Total FDI covered by Orbis is Phantom FDI, which compares
} 
Second, we estimate the value of the shareholders' investment in each of the corporations. Conceptually, FDI can take the form of equity or debt. We measure equity investments in a corporation as shareholders' capital. We cannot directly infer the value of investments by the owners in the form of debt in Orbis since the database does not distinguish between external debt (from banks and other unrelated investors) and internal debt (from affiliates). We overcome this difficulty by assuming that the ratio of internal debt to total debt is 0.2 in all non-financial corporations and that internal debt comes from the owners in proportion to their shareholdings in the corporation. The ratio 0.2 is calibrated so that our aggregates roughly match the ratio between FDI investment in the form of debt and equity in official FDI statistics, which is around 0.25. Hence, for each non-financial corporation we estimate the value of the shareholders' investment as the sum of shareholders' capital and 20 percent of the total debt. For financial corporations, we only include shareholders' capital as most debt between affiliated financial corporations is not classified as FDI according to macroeconomic statistical manuals.

Third, using the ownership information from Orbis, we define $\theta_{c}^{i}$ as the share of corporation $c$ controlled by ultimate investors in economy $i$ and $\lambda_{c}^{h}$ as the share of corporation $c$ owned by immediate investors in economy $i$. With these definitions, we can estimate Orbis-based measures of Real FDI by the economy of the immediate and ultimate owners respectively:

$$
\begin{aligned}
& \text { Real Orbis FDI } I_{h i}^{U I E}=\sum_{c \in \mathbb{H}} \theta_{c}^{i} \text { investment }_{c} \\
& \text { Real Orbis FDI IIE }=\sum_{c \in \mathbb{H}} \lambda_{c}^{i} \text { investment }_{c}
\end{aligned}
$$

where $\mathbb{H}$ is the set of corporations in economy $h$ in our Orbis sample and investment is $_{\text {ine }}$ estimated value of the shareholders' investment in corporation $c$.

To provide a sense of the overall comparability of the firm data in Orbis and official FDI statistics, we note that aggregating the Orbis-based FDI measures across all economies yields a measure of global Real FDI of around $\$ 8.4$ trillion in 2016. This compares to the estimate of global Real FDI of around $\$ 22$ trillion that emerges from our analysis of official FDI statistics in the previous subsection. Presumably, most of the discrepancy is due to the incomplete coverage of the Orbis database; however, it may also partly derive from differences in valuation principles: our Orbis-based measures of investment use book values of equity and debt from firms' financial

to our estimate of around 40 percent based on FDI statistics. The difference plausibly reflects the well-known feature of Orbis that coverage is particularly low in offshore financial centers where accounting information is generally not publicly available from corporate registers (Tørsløv et al., 2018). Moreover, information about number of employees is frequently missing in Orbis, which makes it difficult to identify all SPEs. 
reports whereas FDI statistics use market values whenever possible. ${ }^{24}$

Finally, we use the Orbis-based measures of FDI to produce the conversion factors $\delta_{h i}$. For pairs of economies where the Orbis data deviate less than 50 percent from our estimate of Real FDI and where we therefore expect ownership links in Orbis to be reasonably representative of all FDI, we compute conversion factors that are specific to the pair: ${ }^{25}$

$$
\delta_{h i}=\frac{\text { Real Orbis FDI } I_{h i}^{U I E}}{\text { Real Orbis FDI IIE }} \quad \text { if }\left|\frac{\text { Real Orbis } F D I_{h i}}{\text { Real } F D I_{h i}}-1\right|<0.5 \text { and } h \neq i
$$

The conversion factor simply expresses the ratio, as observed in Orbis, between Real FDI in $h$ from ultimate and immediate owners in $i$ respectively. Multiplying the conversion factor on Real FDI in $h$ by immediate owners in $i$, as estimated from the official FDI statistics, yields an estimate of Real FDI in $h$ by ultimate owners in $i$. The implicit assumption is that the ratio between Real FDI in $h$ by ultimate and immediate owners in $i$ is the same for investment covered and not covered in Orbis. We will probe this assumption below. ${ }^{26}$

We illustrate the mechanics with a concrete example. We estimated above, based on official FDI statistics, that Spain's Real FDI from immediate owners in the United States is around $\$ 23$ billion. We observe around $\$ 13$ billion of this investment in Orbis; hence, the coverage ratio exceeds 50 percent and we proceed to compute a pair-specific conversion factor. The Orbis sample includes investment in Spain from ultimate owners in the United States of around $\$ 29$ billion; hence, Equation (4) yields a conversion factor of 2.2 (i.e. $\$ 29$ billion/ $\$ 13$ billion). Applying Equation (3), we arrive at an estimate of Real FDI in Spain from ultimate owners in the United States of just over $\$ 50$ billion (i.e. $\$ 23$ billion*2.2).

We validate the approach by comparing the conversion factors $\delta_{h i}$ emerging from Orbis with the actual ratio between Real FDI in $h$ by ultimate owners in $i$ and Real FDI in $h$ by immediate owners in $i$ for pairs of economies where both are available: when the host economy belongs to the OECD countries reporting Real FDI by ultimate investor economy and Orbis has sufficient coverage. Figure 5 (upper panel) plots the ranks of the two variables. The rank-rank correlation when observations are weighted with Real FDI is 0.72 , suggesting that our approach creates sensible measures of FDI by ultimate investor economies in the aggregate. The unweighted

\footnotetext{
${ }^{24}$ In practice, FDI statistics use book values extensively because this is often the only information available. However, statistical agencies in some economies apply other valuation methods, e.g. price-to-book value or price-to-earnings, which can have a significant impact on reported data (Damgaard and Elkjaer, 2014).

${ }^{25} \mathrm{We}$ also require that both the numerator and denominator of the ratio defining $\delta_{h i}$ exceed $\$ 1$ million; when this requirement is not met, we proceed as if Orbis deviated more than 50 percent from Real FDI.

${ }^{26}$ All Orbis calculations are based on accounting data for 2016 , which is currently the year with the best coverage. To avoid extreme conversions, $\delta_{h i}$ is capped between 0.05 and 10 .
} 
correlation is 0.43 (not shown) suggesting that the approach yields larger errors for pairs of economies with lower levels of bilateral FDI.

For pairs of economies where Orbis data deviates more than 50 percent from Real FDI, it is an important concern that ownership links in the Orbis sample may not be representative of foreign investment more broadly. To address this concern, we do not use conversion factors that are specific to the pairs of economies when coverage is low, but rather use information from all host economies to compute conversion factors that are specific to the investor economy (and uniform across host economies with low coverage): ${ }^{27}$

$$
\delta_{h i}=\frac{\sum_{h \in \mathbb{S}} \text { Real Orbis } F D I_{h i}^{U I E}}{\sum_{h \in \mathbb{S}} \text { Real Orbis FDI IIE }} \quad \text { if } \quad\left|\frac{\text { Real Orbis } F D I_{h i}}{\text { Real FDI } I_{h i}}-1\right|>0.5 \text { and } h \neq i
$$

where $\mathbb{S}$ is the set of host economies in Orbis. The conversion factor simply expresses the ratio, as observed in Orbis, between global Real FDI from ultimate and immediate investors in $i$ respectively. Again, the conversion factor is applied to Real FDI in $h$ by immediate investors in $i$, as estimated from the official FDI statistics, to obtain an estimate of Real FDI in $h$ by ultimate investors in $h$.

Once again, we illustrate the mechanics with a concrete example. We estimated above, based on official FDI statistics, that Russia's Real FDI from immediate owners in the Netherlands is around $\$ 41$ billion. We observe around $\$ 19$ billion of this investment in Orbis. Hence, the coverage ratio falls below 50 percent and we therefore do not apply a conversion factor specific to the pair Russia-Netherlands, but rather one that is specific to the investor economy the Netherlands. In Orbis, we observe global Real FDI from ultimate investors in the Netherlands of around $\$ 294$ billion and global Real FDI from immediate investors in the Netherlands of around $\$ 597$ billion. Hence, Equation (5) yields a conversion factor of around 0.5 (i.e. $\$ 294$ billion/\$597 billion). Applying Equation (3), we arrive at an estimate of Real FDI in Russia from ultimate owners in the Netherlands of $\$ 21$ billion (i.e. $\$ 41$ billion*0.5). ${ }^{28}$

\subsubsection{Round-tripping and final adjustments}

According to the new FDI statistics from reporting OECD countries as well as the Orbis database, a considerable share of FDI in an economy is assigned to ultimate investors in the

\footnotetext{
${ }^{27}$ We require that both the numerator and denominator of the ratio defining $\delta_{h i}$ exceed $\$ 50$ million; when this requirement is not met, we set $\delta_{h i}=1$.

${ }^{28}$ We show the raw ratio between ultimately owned FDI and immediately owned FDI at the economy level, as observed in Orbis and before any adjustments (see below), for the 50 largest investor economies in the world in Figure A1 in the Online Appendix.
} 
same economy. Such round-tripping can be motivated by many reasons including tax planning. For instance, China's tax system for many years favored foreign investors over domestic investors, which induced many Chinese investors to channel their investments in China through corporations in Hong Kong SAR or other offshore financial centers (Qun, 2008). ${ }^{29}$ To estimate round-tripping FDI for a given economy, i.e. Real FDI in economy $h$ by ultimate investors in economy $h$, we cannot apply a conversion factor to Real $F D I_{h h}$, as we do to estimate FDI for other ultimate investor economies in Equation (3), since Real $F D I_{h h}$ is zero by construction. Instead, we rely on the following equation:

$$
\text { Real FDI } I_{h h}^{U I E}=\frac{\text { Real Orbis FDI } I_{h h}^{U I E}}{\sum_{h \in \mathbb{S}} \text { Real Orbis FDI } I_{h i}^{U I E}} \text { Real FDI } I_{h}^{I I E}
$$

where $\mathbb{S}$ is the set of host economies in Orbis. We refer to the ratio on the right-hand side as the round-tripping factor: it expresses the share of Real FDI in economy $h$ where the ultimate investor is also in economy $h$ as observed in Orbis. To obtain an estimate of round-tripping Real FDI in economy $h$ we multiply this factor with the aggregate inward Real FDI position of economy $h$ as estimated in Section 2.3. ${ }^{30}$ To illustrate, in our Orbis sample, 22 percent of inward FDI in China is by ultimate investors in China. Applying this round-tripping factor to China's total inward FDI position of $\$ 2.7$ trillion, we estimate aggregate round-tripping FDI in China at $\$ 0.6$ trillion (adjusted to $\$ 0.7$ trillion below). ${ }^{31}$

Finally, we adjust FDI positions by ultimate investor economy to make the FDI network internally consistent in the sense that an economy's inward Real FDI, aggregated over immediate investor economies, matches the economy's inward Real FDI, aggregated over ultimate investor economies (including the economy itself to account for round-tripping). Generally, self-reported FDI by ultimate investor economy is almost consistent with FDI by immediate investor economy; the mostly minor discrepancies are likely due to trivial reasons such as the use of different data vintages. However, when we estimate FDI by ultimate investor economies in Equation (3), using CDIS data on FDI by immediate investor economies and conversion factors estimated

\footnotetext{
${ }^{29}$ Similarly, there is evidence that the considerable portfolio investment into the United States from offshore financial centers, at least to some extent, reflects round-tripping by U.S. individuals engaged in tax evasion (Hanlon et al., 2015).

${ }^{30}$ For economies where Real $F D I_{h}^{I I E}$ is below $\$ 50$ million, we apply a global round-tripping factor, defined as global round-tripping FDI in Orbis as a share of global FDI in Orbis rather than the economy-specific roundtripping factor in Equation (6). The economy-specific round-tripping factors are capped at 0 and 0.25 to prevent extreme factors in economies with low Orbis coverage.

${ }^{31}$ We show the raw round-tripping factor, the ratio between inward Real FDI ultimately owned by investors in the economy itself and aggregate inward Real FDI in the economy, as observed in Orbis and before any adjustments (see below), for the 50 largest economies in the world (by inward Real FDI) in Figure A2 in the Online Appendix.
} 
from Orbis, some inconsistencies may arise because the Orbis sample is not fully representative of the population of firms with foreign investors and investments. For each economy in the database, we therefore adjust our raw estimates of inward Real FDI by ultimate investor economy proportionally to ensure consistency. ${ }^{32}$ For instance, aggregating Spain's inward Real FDI over immediate investor economies yields a total of $\$ 624$ billion whereas aggregating over ultimate investor economies yields a total of $\$ 545$ billion. To achieve consistency, we multiply all the raw estimates of Spain's Real FDI by ultimate investor economies with the factor 1.14 (i.e. $\$ 624$ billion / $\$ 545$ billion). Globally, the adjustments we make to achieve consistency between FDI positions by ultimate and immediate investor economies amount to around $\$ 2.8$ trillion or around 8 percent of global FDI.

\subsection{Summary statistics}

We summarize the data sources ultimately used to estimate the database in Table 3. Around 90 percent of the inward Total FDI in the database is reported to the CDIS while the remaining 10 percent is inferred from mirror data or based on our own estimates (first panel). The decomposition into Phantom FDI and Real FDI relies much more on our own estimates: around 50 percent of the global Phantom FDI and 80 percent of Real FDI is estimated from the prediction model. Finally, around one quarter of the allocation of Real FDI to ultimate investor economies derives from reports to the OECD FDI statistics and three quarters are estimated by applying conversion factors based on Orbis data. ${ }^{33}$

\section{Characteristics of the global FDI network}

\subsection{The nature of global FDI}

We first aggregate inward FDI positions across all economies in the world and show, in Figure 6, Total FDI at the global level for the period 2009-2017 with a breakdown on Real FDI (blue bars) and Phantom FDI (red bars). In 2017, global FDI was almost $\$ 40$ trillion with Real FDI accounting for around $\$ 25$ trillion and Phantom FDI accounting for around $\$ 15$ trillion. Over the period 2009-2017, Total FDI increased by around 70 percent reflecting that Phantom FDI almost doubled whereas Real FDI increased by a more modest 50 percent. The share

\footnotetext{
${ }^{32}$ The economy-specific adjustment factor expresses the ratio between the economy's inward Real FDI, aggregated over immediate investor economies, and the raw estimates of the economy's inward Real FDI aggregated over ultimate investor economies.

${ }^{33}$ Only around $5 \%$ of Real FDI is not adjusted due to low coverage in Orbis.
} 
of Phantom FDI in Total FDI increased from just above 30 percent in 2009 to just below 40 percent in $2017 .^{34}$

We conduct a number of sensitivity tests of the estimate of global Phantom FDI in Figure 7 (upper panel). First, we estimate Phantom FDI for economies that do not self-report FDI in SPEs and non-SPEs separately based on a model that does not include Luxembourg (green line). Within the sample of reporting economies, Luxembourg exhibited by far the largest share of Phantom FDI in Total FDI and we noted in Section 2.3 that the parameters of the prediction model were quite sensitive to whether Luxembourg was included or not. Our estimates of global Phantom FDI, however, are very robust to excluding Luxembourg from the prediction model. ${ }^{35}$ Second, we aggregate Phantom FDI across the economies that self-report FDI in SPEs only (blue line). Only relying on self-reported statistics effectively makes the extreme assumption that Phantom FDI is zero in all economies that do not self-report FDI in SPEs (e.g. the British Virgin Islands, Bermuda and the Cayman Islands) and thus provides a lower bound. Even in this extreme scenario, Phantom FDI amounted to around 7.4 trillion globally in 2017. Third, we adopt an ad hoc approach to approximating Phantom FDI in economies that do not self-report FDI in SPEs by assuming that Phantom FDI constitutes 90 percent of Total FDI in offshore centers and 0 percent in other economies (red line). This yields an estimate of global Phantom FDI of around $\$ 20$ trillion in 2017, considerably higher than the baseline estimate of around $\$ 15$ trillion.

While the sensitivity analysis highlights that the incomplete coverage of reported data on FDI in SPEs creates significant uncertainty about the true magnitude of Phantom FDI at the global level, it also illustrates that we do not necessarily err on the high side. On the one hand, if one believes that all of the FDI in non-reporting offshore centers like the British Virgin Islands, Bermuda and the Cayman Islands represent real investment with substantial links to the local economies, one may think that $\$ 7.4$ trillion, or around 20 percent of Total FDI, is the most sensible global estimate of Phantom FDI. One the other hand, if one holds the view that the vast majority of the FDI positions of offshore centers reflect pass-through investment, $\$ 20$ trillion, or around 50 percent of Total FDI, may be a more accurate number than our baseline estimate of $\$ 15$ trillion.

Finally, we note that our estimates of Phantom FDI are sensitive to the particular definition

\footnotetext{
${ }^{34}$ This is consistent with studies showing that FDI positions vis-a-vis offshore financial centers have grown faster than other FDI positions since the global financial crisis (Lane and Milesi-Ferretti, 2018).

${ }^{35}$ Intuitively, excluding Luxembourg reduces the gradient in the prediction model but raises the intercept as shown in Figure 4; hence the model predicts a higher share of Real FDI in economies with high levels of FDI (relative to GDP) but a smaller share in economies with a moderate level of FDI.
} 
of SPEs applied by national statistical authorities. Since there is currently no strictly harmonized international SPE definition, national compilers have some measure of flexibility (as described in Section 2.1). To illustrate the issue, Ireland does not currently report a breakdown of Total FDI into SPEs and non-SPEs in official OECD statistics, but a recent publication from Ireland's Central Statistics Office (2019) estimates that FDI into SPEs only accounts for 5 percent of Irish FDI. By contrast, Galstyan (2019) estimates that distortions to Irish FDI - primarily from redomiciled public limited companies, IP transfers and aircraft leasing - account for 47 percent of Ireland's inward FDI, which is roughly consistent with our estimate that 62 percent of Total FDI into Ireland is in SPEs. The low estimate produced by the Central Statistics Office (2019) is based on the SPE definition recently proposed by the international statistical community (IMF, 2018). This definition is more restrictive than the description in the current manuals, for instance by applying a cap of five employees, and therefore categorizes fewer entities as SPEs. In the case of Switzerland, our model generates an SPE share of 50 percent compared to only 13 percent in official Swiss statistics. In this context, the Swiss National Bank (2017) underscores that a narrow definition of SPEs leads to underestimation of pass-through FDI as significant FDI will pass through entities that are categorized as non-SPEs.

\subsection{Phantom FDI, Real FDI and round-tripping by economy}

We describe how the $\$ 15$ trillion of Phantom FDI is distributed across economies in Figure 7 (lower panel). The global leader is Luxembourg with a Phantom FDI position of around $\$ 3.8$ trillion, closely followed by the Netherlands with around $\$ 3.3$ trillion. These positions are self-reported by the national statistical authorities (indicated with dark red bars) and therefore not subject to the uncertainties associated with our estimation method. The following five economies are known offshore financial centers - Hong Kong SAR, the British Virgin Islands, Bermuda, Singapore and the Cayman Islands - each accounting for Phantom FDI around \$0.5-1 trillion. These positions are estimated using the method developed above (indicated with light red bars) and therefore subject to some uncertainty.

Next, we turn to the distribution of the global $\$ 25$ trillion of Real FDI across economies in Figure 8 (upper panel). We plot both Real FDI hosted in the economy (blue bars) and Real FDI ultimately controlled by investors in the economy (green bars) for the 20 economies with the largest inward Real FDI position. The United States has the largest inward and outward positions; it hosts Real FDI of around $\$ 4$ trillion and ultimately owns Real FDI of around \$3.6 trillion. Many large economies have highly unbalanced Real FDI positions: China's inward 
position exceeds its outward position by around $\$ 1.2$ trillion whereas the three largest European economies (i.e. Germany, the United Kingdom and France) have a joint outward position that exceeds the joint inward position by around $\$ 1.5$ trillion. A handful of the economies with the largest Real FDI positions also appeared among the economies with the largest Phantom FDI positions. It is noteworthy that at least some of these economies (e.g. the Netherlands, Singapore and Hong Kong SAR) have strikingly balanced Real FDI positions, which is suggestive that the Real FDI estimates for these economies include an important element of pass-through investment. Possibly, some pass-through investment is handled by corporate entities that also have real activities, in which case the entities are categorized as non-SPEs and the investment as real.

We highlight the important distinction between ultimate and immediate ownership in Figure 8 (lower panel). For each of the 20 largest investor economies in the world, the figure shows the ratio between ultimately owned Real FDI, the measure of an economy's real aggregrate outward FDI position emerging from our analysis, and immediately owned Total FDI, the measure of the aggregate outward FDI position in standard FDI statistics. Generally, the estimated ratios are close to unity for large developed economies such as Italy, France, Spain, Germany and Japan, reflecting that standard FDI statistics provide an accurate picture of their aggregate outward FDI position. In the United States and the United Kingdom, the estimated ratios are below unity reflecting that standard FDI statistics overstate their aggregate outward FDI position. A similar pattern emerges, but much more pronounced, for offshore financial centers like Luxembourg, Hong Kong SAR, Bermuda and the British Virgin Islands where much of the outward FDI is ultimately owned by investors in other economies. The opposite holds for China where an estimated ratio above two suggests that Chinese investors are the ultimate owners of more than twice as much FDI as indicated by their outward FDI position in standard FDI statistics.

Finally, we illustrate the economic significance of round-tripping in Figure 9 (upper panel). For each of the 20 largest economies in the world, the figure shows the share of real inward FDI ultimately owned by investors in the economy itself. For some economies, the roundtripping share is based on FDI data by ultimate investor economies reported by the national statistical authorities (indicated with dark red bars). For others, it is based on the Orbis database and therefore subject to more uncertainty (indicated with light red bars). There is considerable variation in the significance of round-tripping across economies. In transition economies like China and Russia, around 25 percent of Real FDI is ultimately owned by domestic 
investors whereas the share is far below 10 percent, and sometimes completely negligible, in most developed economies.

\subsection{Real bilateral investment links}

Standard FDI statistics may misrepresent the strength of cross-border investment links by confounding real and phantom investment and by defining investment ties in terms of immediate rather than ultimate ownership. We illustrate this point in Figure 9 (lower panel) for the five largest economies in world: the United States, China, Japan, Germany and the United Kingdom. For each pair of economies, we plot both our measure of the real link, the value of Real FDI in one economy ultimately owned by investors in the other economy (blue bars), and the measure of the FDI link available in standard statistics, the value of Total FDI in one economy immediately owned by investors in the other economy (green bars). For almost all of the 20 pairs, the real FDI link is underestimated in standard FDI statistics and sometimes very substantially so. For instance, FDI in Germany from the United States is around $\$ 90$ billion according to CDIS whereas our analysis suggests a Real FDI link of almost $\$ 170$ billion. The likely explanation is that a large share of the direct investments made by U.S. multinationals in Germany are channeled through economies like Luxembourg and the Netherlands, which conceals the real strength of the investment links.

We make this point more generally by showing how gravity factors shape different types of bilateral FDI positions in Table 4. We first estimate the following simple gravity model with OLS:

$$
\log \left(F D I_{h i t}\right)=\alpha+\beta_{1} \log \left(G D P_{h t}\right)+\beta_{2} \log \left(G D P_{i t}\right)+\beta_{3} \log \left(\text { Distance }_{h i}\right)+\gamma X_{\text {hit }}+\epsilon_{\text {hit }}
$$

where $X$ is a vector of dummies including contiguity, common language, colonial links etc. and where $h$ denotes the host economy, $i$ the investor economy and $t$ the year. The model yields elasticities of Total FDI with respect to the GDPs of the host economy and the immediate investor economy far below unity, suggesting that the relative importance of foreign investment decreases quickly with market sizes, and an R-squared of 0.266 (Column 1). Estimating the same

model for Phantom FDI and Real FDI separately yields very different results. Most strikingly, the elasticity of Phantom FDI with respect to host economy GDP is negative, suggesting that smaller economies attract more Phantom FDI in absolute terms, whereas the elasticity of Real FDI with respect to host economy GDP is positive and somewhat larger than for Total FDI (Columns 2-3). Finally, including the characteristics of the ultimate investor economy rather 
than the immediate investor economy yields larger coefficients than the baseline model on real variables such as market size and distance and an R-squared of 0.334 (Column 4).

Estimating gravity models in log-levels with OLS may lead to biased estimates because observations with zero FDI are dropped (Silva and Tenreyro, 2006). When we estimate the model on its multiplicative form with a Poisson estimator to retain zero observations, we obtain even more striking results: the coefficient on the market size variables increases from around 0.55 when considering Total FDI by immediate investor economy (Column 5) to around 0.80 when considering our estimates of Real FDI by ultimate investor economy (Column 8). This is consistent with the notion that standard FDI statistics systematically underestimate the real investment links between large economies because much of the investment is channeled through small offshore financial centers.

\subsection{Exposure to tax avoidance opportunities}

Phantom corporations in low-tax economies give multinational firms a number of opportunities to avoid taxes in the high-tax economies where the real investments and the ultimate investors are located. First, phantom corporations may be the notional owners of financial assets (Clifford, 2019), intangible assets (Dischinger and Riedel, 2011) and patents (Karkinsky and Riedel, 2012), which generate income that would otherwise be booked and taxed in affiliates with real activities. Second, they may facilitate the use of hybrid financial instruments (Johannesen, 2014; Hardeck and Wittenstein, 2018), which artificially create deductible interest expenses to offset taxable business income. Third, they allow firms to accumulate and manage profits earned on foreign activities and thus postpone repatriation taxes in the ultimate investor economies (Foley et al., 2007). Fourth, they may serve to reduce or eliminate taxes on cross-border capital flows inside the firm by exploiting tax treaty networks (Weyzig, 2013; Arel-Bundock, 2017) and (Johannesen, 2012).

We attempt to quantify the exposure to these types of tax avoidance opportunities, by estimating, for each economy in the world, the share of its outward FDI where a foreign phantom corporation receives the investment and the share of its inward FDI where a foreign phantom corporation is the investor. ${ }^{36}$

To estimate exposure to tax avoidance through outward FDI, we often need to assume that, for a given economy, the share of inward Total FDI into phantom corporations is the same for all counterpart economies. For instance, when Luxembourg reports that around 95 percent of

\footnotetext{
${ }^{36}$ Exposure estimates for all economies in the world with FDI exceeding $\$ 100$ million are available at https: //nielsjohannesen.net/FDIdatabase/ for the period 2009-2017.
} 
inward Total FDI is Phantom FDI, we assume that this share applies to all economies' outward FDI to Luxembourg. Similarly, when Sweden reports that only around 5 percent of inward Total FDI is Phantom FDI, we assume that this share applies to all economies' outward FDI to Sweden. Cross-sectional differences in our measure of exposure therefore, to a large extent, reflect differences in the counterpart economies of outward FDI. For instance, we will estimate a higher exposure for economies investing relatively more in Luxembourg than for economies investing relatively more in Sweden.

We illustrate estimated exposure to tax avoidance through outward FDI in Figure 10 (upper panel) for the 20 largest economies in the world (by GDP). The cross-sectional variation is very significant: exposure ranges from less than 10 percent in Spain to more than 80 percent in Brazil. The relatively high estimated exposure for the United States (dark bar) is consistent with the argument that U.S. firms face particularly strong incentives to channel foreign investments through low-tax economies (Altshuler and Grubert, 2005). ${ }^{37}$

To estimate exposure to tax avoidance through inward FDI, we need to make two types of assumptions. First, for economies not self-reporting FDI in SPEs and non-SPEs separately, we need an estimate of outward Phantom FDI. In self-reporting economies, we observe that the ratio between outward and inward Phantom FDI is close to unity in the aggregate. ${ }^{38}$ Presumably, this reflects that the vast majority of phantom corporations are "pass-through" entities with inward and outward investment positions matching almost perfectly. We assume that the pattern is the same for non-reporting economies. Therefore, starting from the estimates of inward Phantom FDI obtained in section 3.3, we produce an estimate of outward Phantom FDI by applying the observed ratio between outward and inward Phantom FDI in the aggregate of reporting economies. Second, mirroring the assumption made above for inward FDI, we assume that, for a given economy, the share of outward Total FDI coming from phantom corporations is uniform across counterpart economies. For instance, Luxembourg reports that 95 percent of outward Total FDI is Phantom FDI, and we assume that this share applies uniformly to all economies' inward FDI from Luxembourg. ${ }^{39}$

\footnotetext{
${ }^{37}$ The so-called check-the-box rules allow U.S. firms that channel foreign investments through low-tax economies to reduce corporate taxation in economies hosting the investment with the usual profit shifting techniques without triggering the so-called controlled-foreign-company (CFC) rules in the United States. The tax reform implemented in early 2018 has reduced the incentives for U.S. firms to invest in empty corporate shells, for instance by moving from a worldwide to a territorial corporate tax, imposing a one-off tax on non-repatriated foreign profits and introducing a de facto minimum tax on intangible assets in foreign subsidiaries.

${ }^{38}$ The precise ratio varies between 1.15 and 1.18 over the period 2009-2017 reflecting that SPEs can also receive other types of financing, e.g. portfolio investment.

${ }^{39}$ Figure A4 in the Online Appendix empirically assesses the assumption of uniform ratios across counterpart economies for the sample of economies where ratios are reported for each counterpart economy separately.
} 
We illustrate estimated exposure to tax avoidance through inward FDI in Figure 10 (lower panel) for the 20 largest economies in the world (by GDP). The cross-sectional variation is somewhat smaller than for exposure through outward FDI: the estimates range from around 15 percent in Australia to around 60 percent in Russia. For the United States (dark bar), the contrast to Figure 9 (upper panel) is striking: while more than half of its outward FDI is channeled through phantom corporations, only a bit more than one quarter of its inward FDI derives from such corporations.

Finally, we estimate how the estimated exposure to tax avoidance correlates with corporate tax rates and levels of economic development in the cross-section of economies in Table 5. Exposure through outward FDI is significantly higher in economies with higher corporate tax rates: raising the tax rate by 10 percentage points is associated with an increase in exposure through outward FDI of more than 5 percentage points (Column 1). This is consistent with earlier literature highlighting the importance of taxation in the investor economy for the decision to operate through low-tax economies (Desai et al., 2006). The tax gradient is significantly steeper in less developed economies: at the lowest levels of GDP per capita, raising the tax rate by 10 percentage points is associated with an increase in exposure through outward FDI of more than 15 percentage points (Column 2). This is consistent with evidence that profit shifting responds more strongly to tax incentives in less developed economies where tax enforcement is weaker (Johannesen et al., 2016). Similar relationships emerge, but somewhat less clearly, for exposure through inward FDI (Columns 3-4). ${ }^{40}$

\section{Conclusion}

Standard FDI statistics are distorted by offshore centers with enormous inward and outward investment positions. The first part of the paper documents the estimation of the global FDI network with a decomposition of Total FDI into Real FDI, relations between ultimate investors in one economy and substantial business activities in another, and Phantom FDI, investment into empty corporate shells with no substance and no real links to the local economy. The second part describes key features of the estimated FDI network. Our estimates imply that Phantom FDI has grown at a faster pace than Real FDI over the last decade and accounts for around $\$ 15$ trillion, almost 40 percent of Total FDI, globally. Most of the world's Phantom FDI is in a small group of well-known offshore centers: Luxembourg ( $\$ 3.8$ trillion), the Netherlands (\$3.3 trillion), Hong Kong SAR (\$1.1 trillion), British Virgin Islands (\$0.8 trillion), Bermuda

\footnotetext{
${ }^{40}$ The statistical power of the model is limited suggesting that other factors play a role too.
} 
(\$0.8 trillion), Singapore ( $\$ 0.8$ trillion) and the Cayman Islands ( $\$ 0.7$ trillion). The real FDI links between the largest economies in the world are much higher than implied by standard FDI statistics based on immediate ownership because a significant share of FDI is channelled through offshore centers. 


\section{References}

[1] Alfaro, L., Chanda, A., Kalemli-Ozcan, S. and Sayek, S., 2004. "FDI and economic growth: the role of local financial markets." Journal of International Economics 64(1), pp. 89-112.

[2] Alstadsæter, A., Johannesen, N., Zucman, G., 2019. "Tax Evasion and Inequality." American Economic Review 109(6), pp. 2073-2103.

[3] Altshuler, R. and Grubert, H., 2005. "The three parties in the race to the bottom: host governments, home governments and multinational companies." Florida Tax Review 7, p. 153.

[4] Arel-Bundock, V., 2017. "The unintended consequences of bilateralism: Treaty shopping and international tax policy. "International Organization 71(2), pp. 349-371.

[5] Becker, J., Johannesen, N. and Riedel, N., 2018. "Taxation and the allocation of risk inside the multinational firm." CESifo Working Paper Series No. 7033

[6] Borensztein, E., De Gregorio, J., Lee, J. W., 1998. "How does foreign direct investment affect economic growth?" Journal of International Economics 45(1), pp- 115-135.

[7] Casella, B., 2019. "Looking through conduit FDI in search of a probabilistic approach." Transnational Corporations 26(1), pp. 109-146.

[8] Central Statistics Office, 2019. "Foreign Direct Investment in Ireland 2017."

[9] Clifford, S., 2019. "Taxing multinationals beyond borders: financial and locational responses to CFC rules." Journal of Public Economics 173, pp. 44-71.

[10] Damgaard, J. and Elkjaer, T., 2014. "Foreign Direct Investment and the External Wealth of Nations: How Important Is Valuation?" Review of Income and Wealth 60(2), pp.245-260.

[11] Damgaard, J. and Elkjaer, T., 2017. "The global FDI network: searching for ultimate investors." International Monetary Fund.

[12] Desai, M.A., Foley, C.F. and Hines Jr, J.R., 2004. "A multinational perspective on capital structure choice and internal capital markets." Journal of Finance 59(6), pp. 2451-2487.

[13] Desai, M.A., Foley, C.F. and Hines Jr, J.R., 2006. "The demand for tax haven operations." Journal of Public economics 90(3), pp.513-531.

[14] Dischinger, M., Riedel, N., 2011. "Corporate Taxes and the Location of Intangible Assets within Multinational Firms." Journal of Public Economics 95 (7-8), pp. 691-707.

[15] Dreher, A., 2006. "Does globalization affect growth? Evidence from a new index of globalization." Applied economics 38(10), pp. 1091-1110. 
[16] Dyreng, S., Lindsey, B., Thornock, J., 2013. "Exploring the role Delaware plays as a domestic tax haven." Journal of Financial Economics 108, pp. 751-772.

[17] Galstyan, V., 2019. "Estimates of Foreign Assets and Liabilities for Ireland." Research Technical Papers 3/RT/19 Central Bank of Ireland.

[18] Garcia-Bernardo, J., Fichtner, J., Takes, F.W. and Heemskerk, E.M., 2017. "Uncovering offshore financial centers: Conduits and sinks in the global corporate ownership network." Scientific Reports 7(1), p.6246.

[19] Griffith, R., Miller, H. and O'Connell, M., 2014. "Ownership of intellectual property and corporate taxation." Journal of Public Economics 112, pp. 12-23.

[20] Grubert, H. and Slemrod, J., 1998. "The effect of taxes on investment and income shifting to Puerto Rico." Review of Economics and Statistics 80(3), pp.365-373.

[21] Haberly, D. and Wójcik, D., 2015. "Tax havens and the production of offshore FDI: an empirical analysis." Journal of Economic Geography 15(1), pp. 75-101.

[22] Hanlon, M., Maydew, E.L. and Thornock, J.R., 2015. "Taking the long way home: US tax evasion and offshore investments in US equity and debt markets." The Journal of Finance 70(1), pp.257-287.

[23] Harding, T. and Javorcik, B.S., 2012. "Foreign direct investment and export upgrading." Review of Economics and Statistics 94(4), pp. 964-980.

[24] Harding, T. and Javorcik, B.S., 2011. "Roll out the red carpet and they will come: Investment promotion and FDI inflows. "Economic Journal 121(557), pp. 1445-1476.

[25] Hardeck, I. and Wittenstein, P.U., 2018. "Assessing the tax benefits of hybrid arrangementsevidence from the Luxembourg leaks "National Tax Journal 71(2), pp. 295-334.

[26] Hines Jr, J.R., 1996. "Altered States: Taxes and the Location of Foreign Direct Investment in America." American Economic Review, pp. 1076-1094.

[27] Hines Jr, J.R. and Rice, E.M., 1994. "Fiscal paradise: Foreign tax havens and American business." Quarterly Journal of Economics 109(1), pp. 149-182.

[28] Hines Jr, J.R., 2010. "Treasure islands." Journal of Economic Perspectives 24(4), pp. 10326.

[29] IMF, 2009. "Balance of Payments and International Investment Position Manual", Sixth Edition (BPM6)."

[30] IMF, 2018. "Final Report of the Task Force on Special Purpose Entities." IMF Committee on Balance of Payments Statistics (BOPCOM), BOPCOM-18/03. 
[31] Javorcik, S. B., 2004. "Does foreign direct investment increase the productivity of domestic firms? In search of spillovers through backward linkages." American Economic Review 94(3), pp. 605-627.

[32] Javorcik, B. and Poelhekke, S., 2017. "Former foreign affiliates: Cast out and outperformed?" Journal of the European Economic Association 15(3), pp. 501-539.

[33] Johannesen, N., 2012. "Optimal fiscal barriers to international economic integration in the presence of tax havens." Journal of Public Economics 96(3-4), pp. 400-416.

[34] Johannesen, N., 2014. "Tax Avoidance with Cross-border Hybrid Instruments." Journal of Public Economics 112, pp. 40-52.

[35] Johannesen, N., Tørsløv, T., Wier, L., 2016 "Are less developed countries more exposed to multinational tax avoidance? Method and evidence from micro-data."WIDER Working Paper 2016/10, forthcoming in World Bank Economic Review

[36] Johannesen, N., Zucman, G., 2014. "The End of Bank Secrecy? An Evaluation of the G20 Tax Haven Crackdown". American Economic Journal: Economic Policy 6(1), pp. 65 - 91.

[37] Karkinsky, T., Riedel, N., 2012. "Corporate Taxation and the Location of Patents within Multinational Firms." Journal of International Economics 88(1), pp. 176-185.

[38] Lane, P. and Milesi-Ferretti, G.M., 2018. "The External Wealth of Nations Revisited: International Financial Integration in the Aftermath of the Global Financial Crisis. "IMF Economic Review 66(1), pp. 189-222.

[39] Noonan, R., 2019. "Special Purpose Vehicles and Pass-through Equity: a Micro-analysis with BEA Data.", Paper prepared for the 62nd ISI World Statistics Congress.

[40] OECD, 2008. "OECD Benchmark Definition of Foreign Direct Investment", Fourth Edition (BMD4).

[41] OECD, 2019. "OECD/G20 Inclusive Framework on BEPS Progress report July 2018 - May $2019 "$

[42] Qun, L.I., 2008. "Tax incentive policies for foreign-invested enterprises in China and their influence on foreign investment." Revenue Law Journal 18(1), p. 6702.

[43] Silva, J.S. and Tenreyro, S., 2006. "The log of gravity. " The Review of Economics and Statistics 88(4), pp. 641-658.

[44] Swiss National Bank, 2017. "Direct Investment 2016."

[45] Tørsløv, T., Wier, L., Zucman, G., 2018. "The Missing Profits of Nations." NBER Working Paper 24701. 
[46] Weyzig, F., 2013. Tax treaty shopping: structural determinants of Foreign Direct Investment routed through the Netherlands." International Tax and Public Finance 20(6), pp. 910-937.

[47] Zoromé, A., 2007. "Concept of offshore financial centers: In search of an operational definition (No. 7-87)." International Monetary Fund.

[48] Zucman, G., 2014. "Taxing across borders: Tracking personal wealth and corporate profits." Journal of Economic Perspectives 28(4), pp. 121-48. 
Figure 1 - Largest inward FDI positions in 2017. The figure shows the 20 economies with largest inward FDI positions in 2017. For economies reporting to CDIS, the figure shows the reported numbers. For non-reporting economies, the figure shows our estimates.

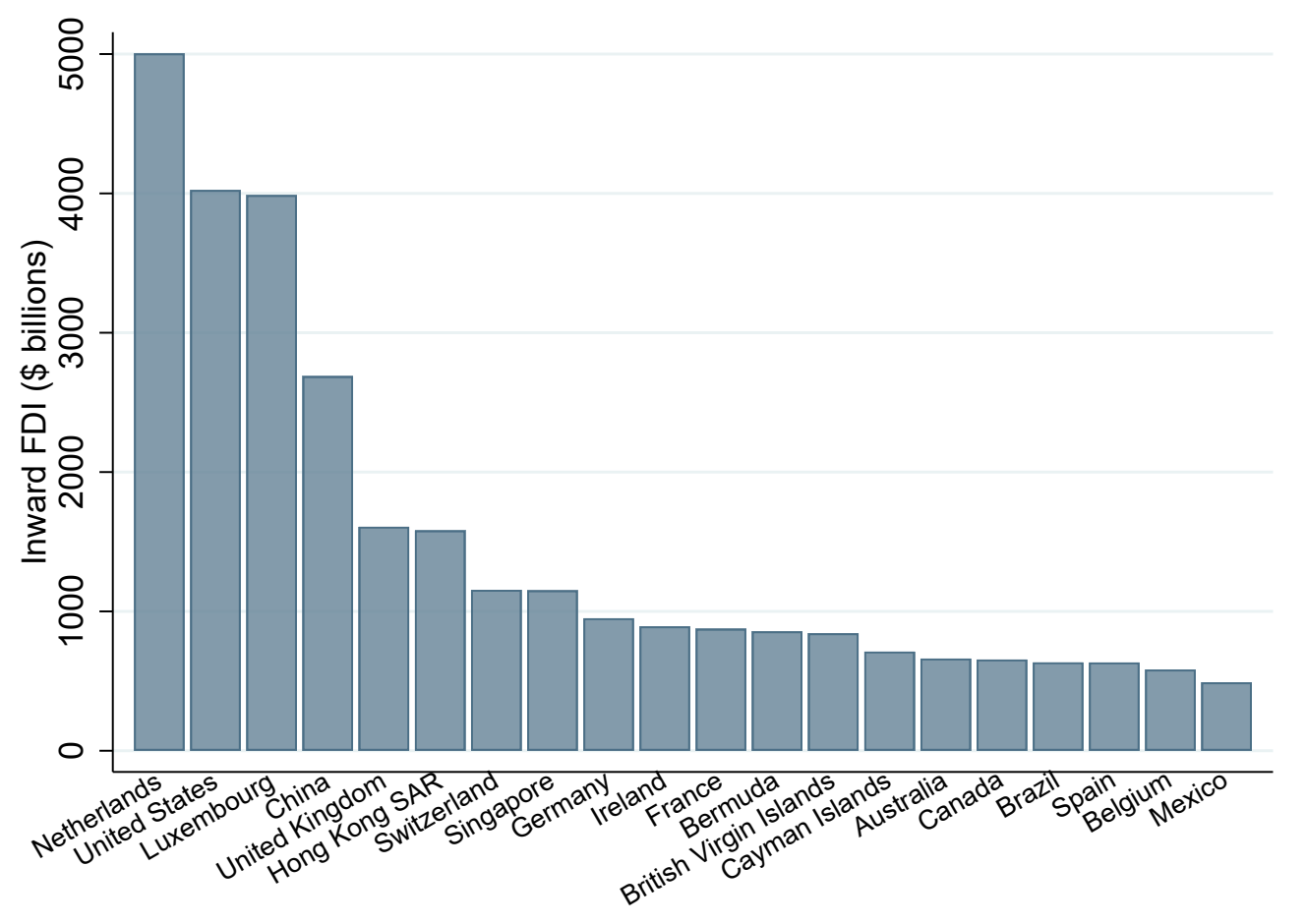


Figure 2 - Prediction model and predictions. Top panel: the figure shows the ratio of Total FDI to GDP (x-axis) plotted against the ratio of Real FDI to Total FDI (y-axis) for the OECD countries reporting non-zero Phantom FDI. Bottom Panel: the figure shows the relation between between Total FDI/GDP and Real FDI/Total FDI. For economies reporting non-zero Phantom FDI to the OECD, Real FDI/Total FDI corresponds to the reported values (green dots). For non-reporting economies, Real FDI/Total FDI corresponds to predicted values (blue dots).
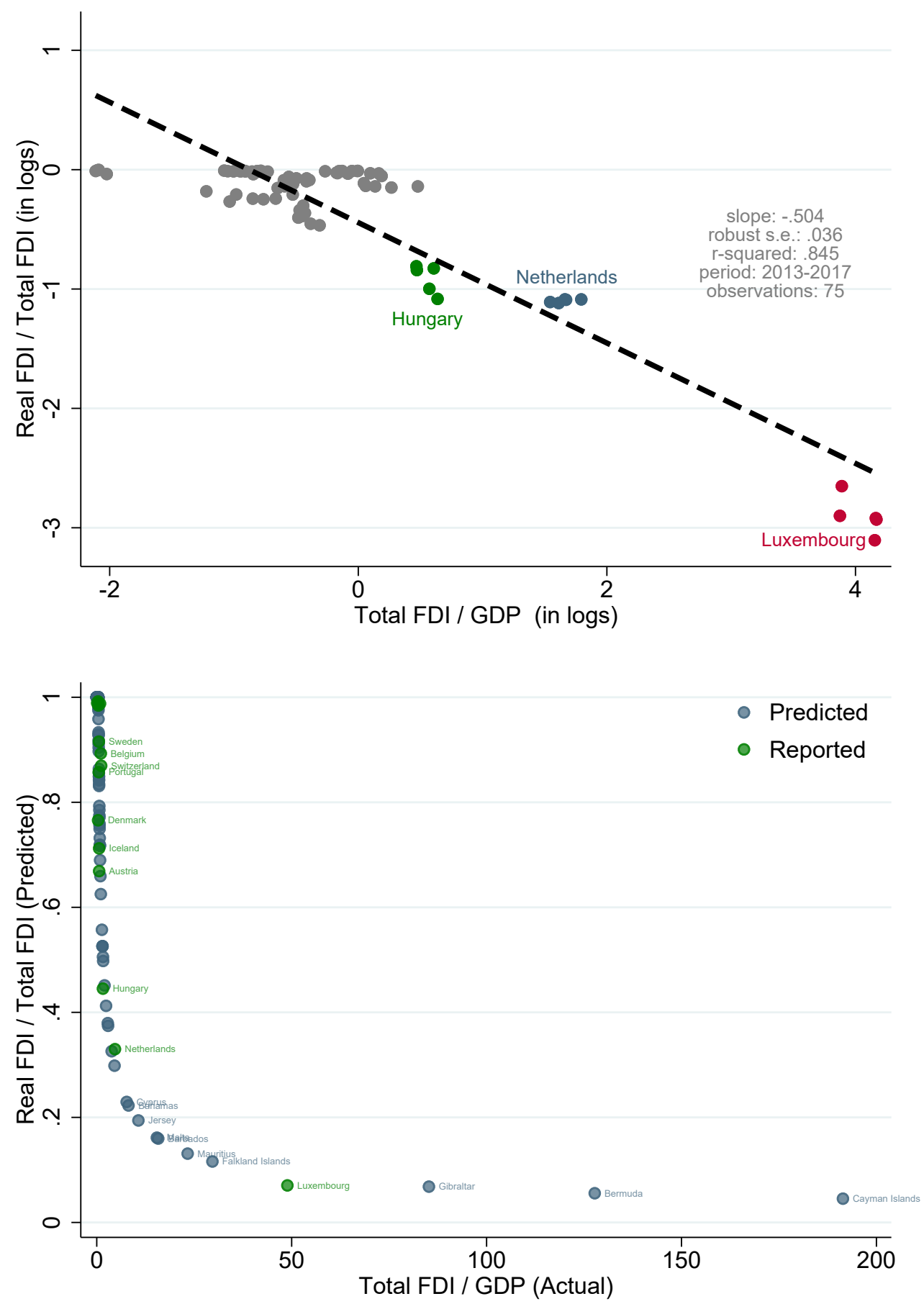
Figure 3 - Model sensitivity. Top panel: the figure illustrates the sensitivity of the estimated univariate relation between Total FDI / GDP and Real FDI / Total FDI to observations from individual economies. Each regression line corresponds to a regression where one economy is removed from the sample. The figure highlights the regression lines corresponding to regressions where Hungary (green), Netherlands (blue) and Luxembourg (red) are removed. Bottom Panel: the figure illustrates the sensitivity of the estimated univariate relation between Total FDI / GDP and Real FDI / Total FDI to sample period. Each regression line corresponds to a regression with observations from only one year.
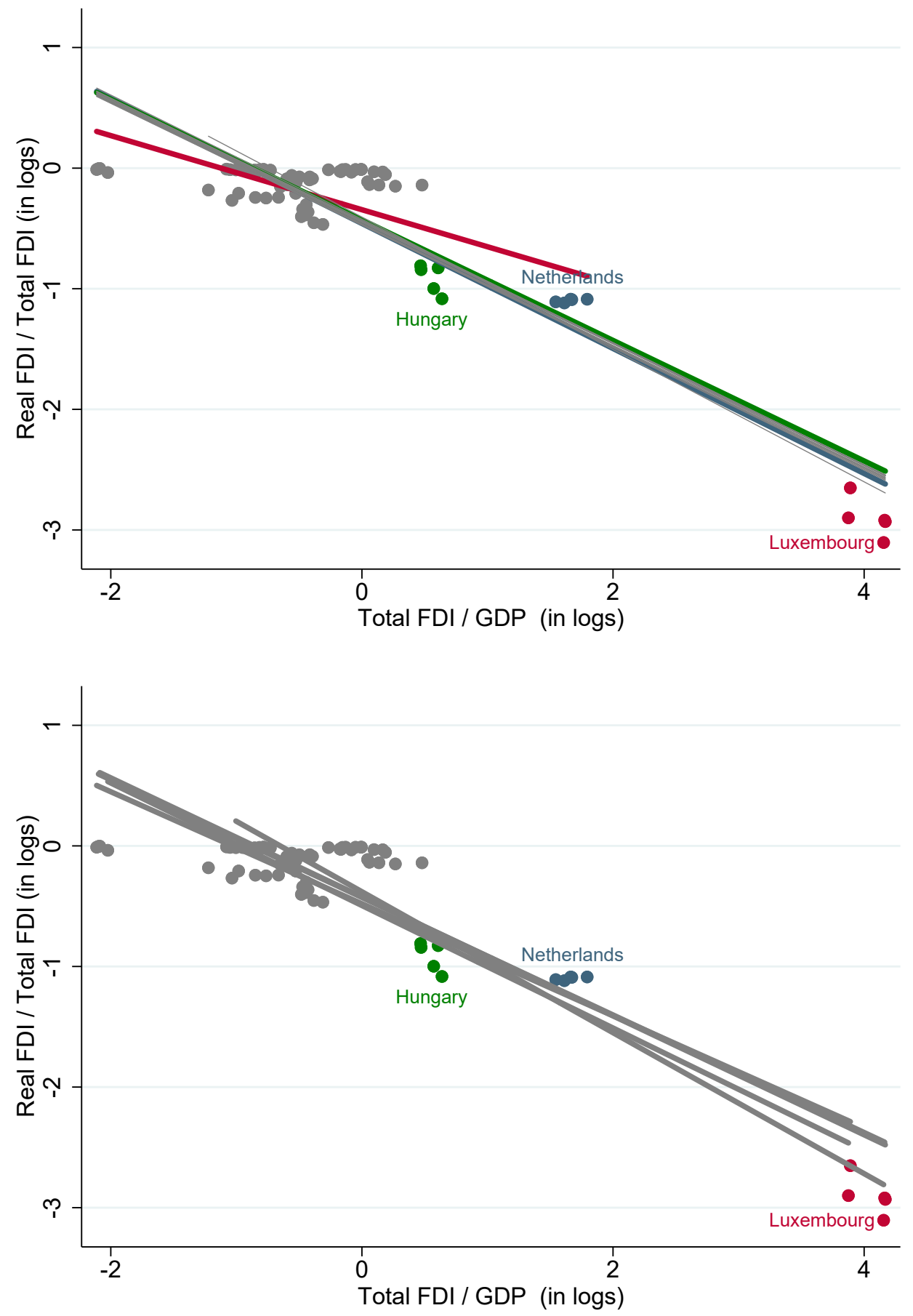
Figure 4 - Sensitivity of predictions. Top panel: the figure shows how the predicted values of Real FDI/Total FDI depend on the model used to make the predictions. The figure plots Real FDI/Total FDI predicted by the baseline univariate model on the x-axis against Real FDI/Total FDI predicted by the multivariate model with a full set of controls (blue dots), the univariate model excluding observations for Luxembourg from the estimation sample (red dots) and the univariate model using only observations from 2017 (green dots) on the y-axis. Bottom panel: the figure shows the estimated Real FDI/Total FDI by economy. Economies where the ratio is unity are not shown. The figure distinguishes between economies belonging to a broad set of offshore financial centers (red) and other economies (blue).
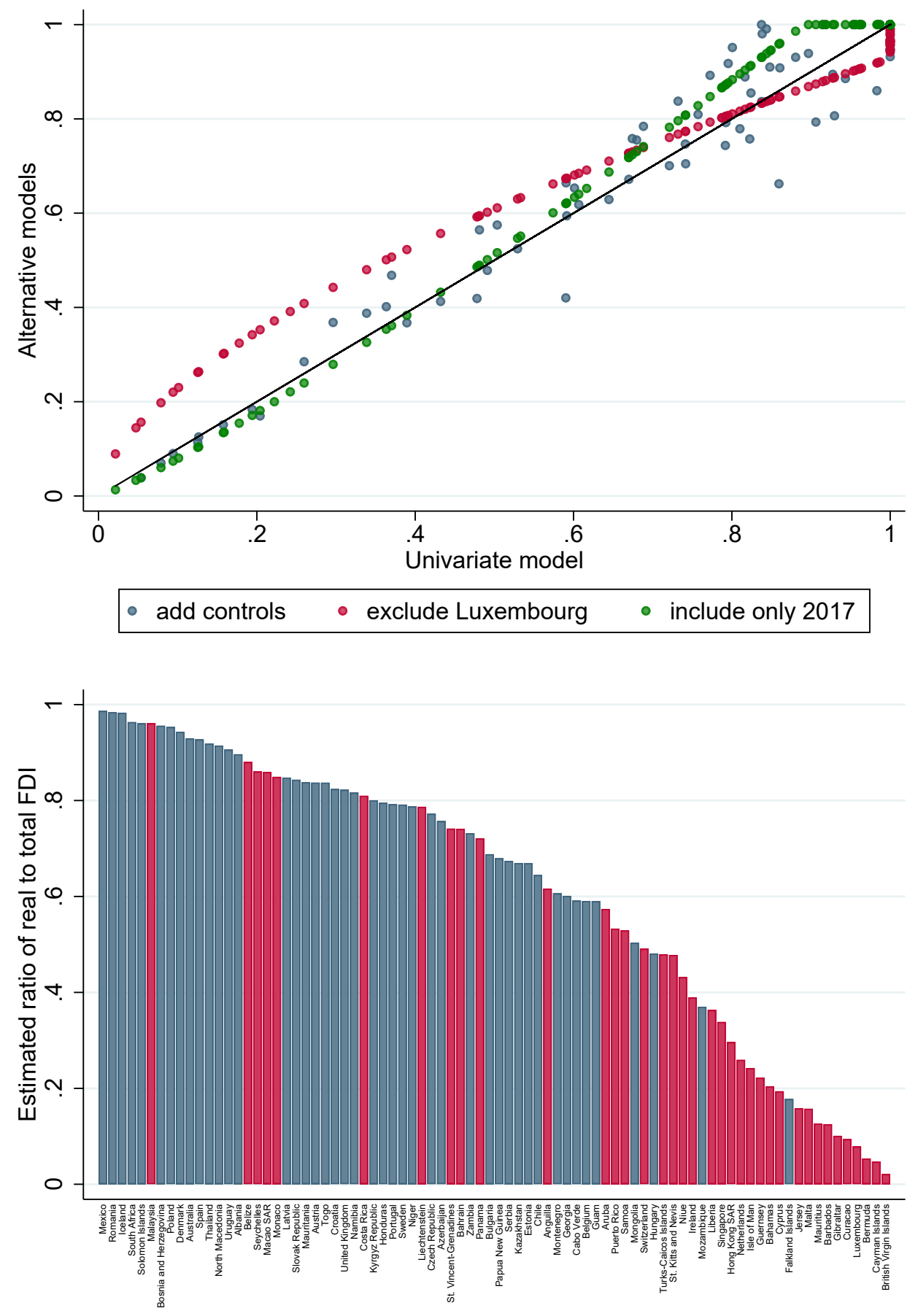
Figure 5 - Validation of Orbis approach. The figure illustrates the results from a test of our approach to estimating FDI by ultimate investor economy using micro-data from Orbis. For each pair of economies where the value of real investments in Orbis accounts for at least 50 percent of the Real FDI position and where the host country self-reports Real FDI by ultimate investor economy, the figure plots the conversion factor computed with Orbis data (i.e. the ratio of Real Orbis FDI in $h$ by ultimate investors in $i$ to Real Orbis FDI in $h$ by immediate investors in $i$ as defined in Equation (4)) against the equivalent ratio in self-reported FDI data. Observations are weighted by the value of Real FDI. The regression line illustrates the parameters of the (weighted) univariate regression.

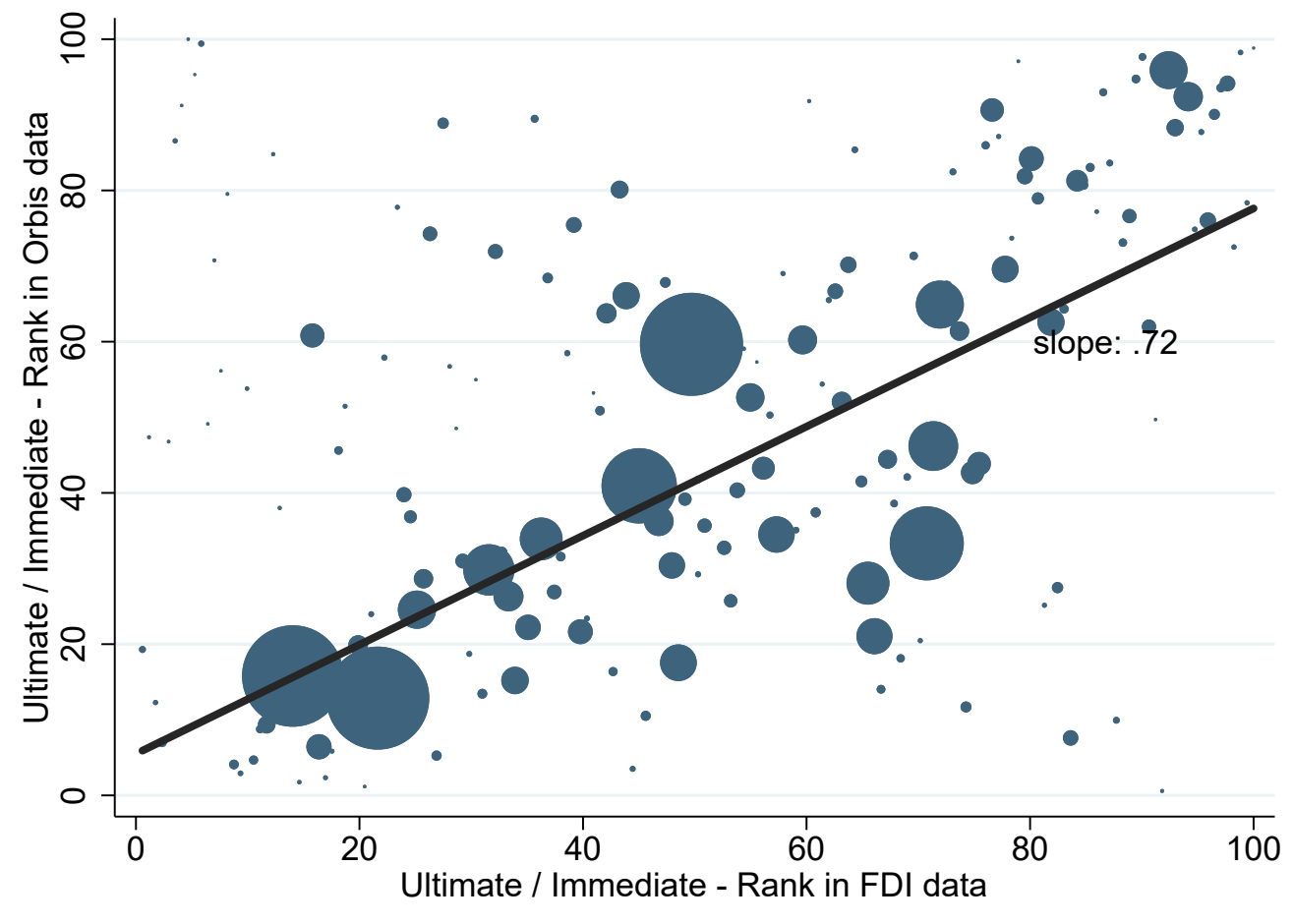


Figure 6 - Global Real and Phantom FDI. The figure shows the evolution of inward FDI positions aggregated over all economies in the world over the period 2009-2017. Total FDI is decomposed into Real FDI (blue bars) and Phantom FDI (red bars).

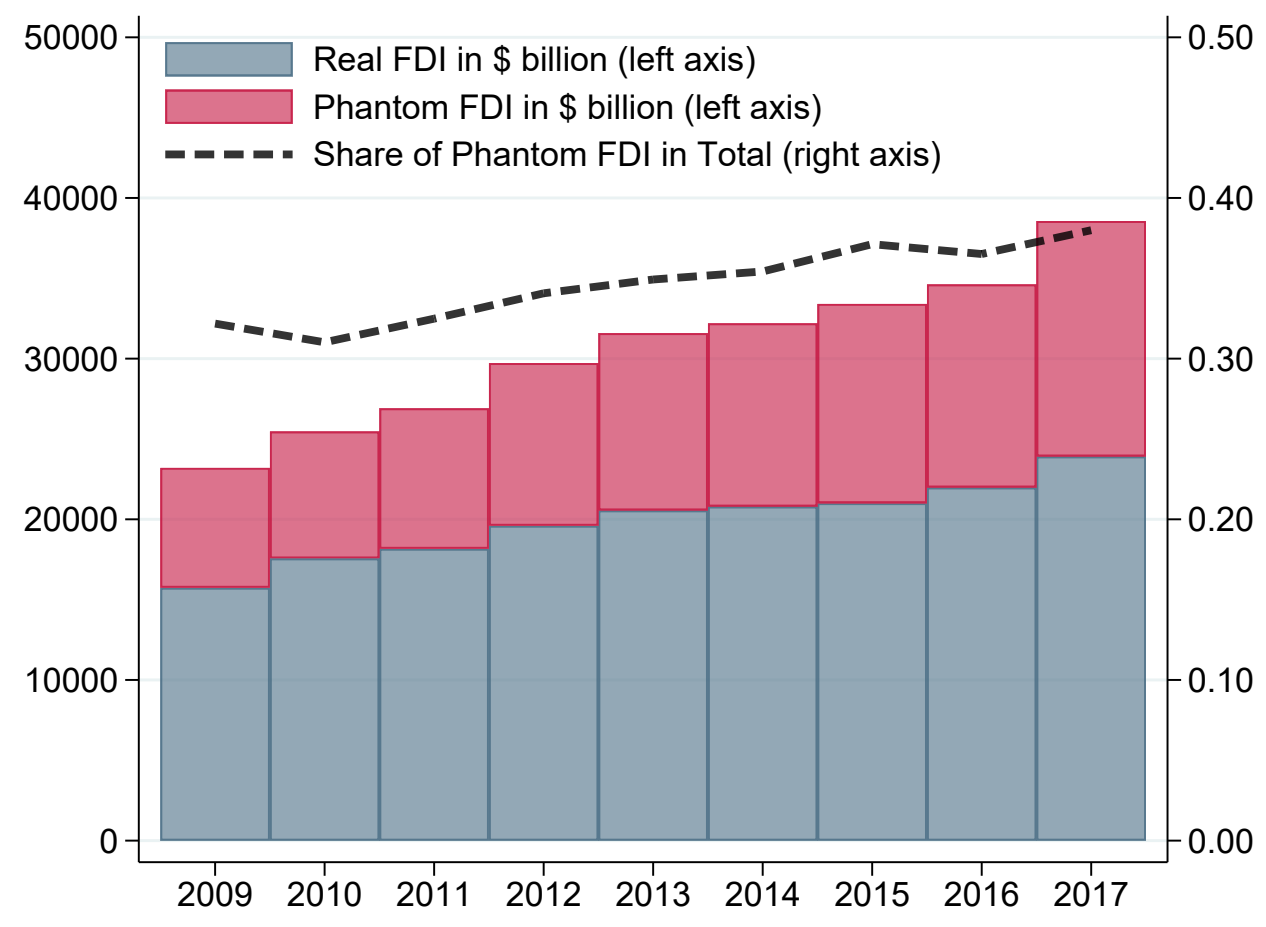


Figure 7 - Phantom FDI Top panel: the figure compares our baseline estimates of global Phantom FDI over the period 2009-2017 (black line) to three alternative scenarios: assuming zero Phantom FDI in economies that do not self-report FDI in SPEs and non-SPEs separately so that the Phantom FDI estimate only reflects self-reported FDI in SPEs (blue line); estimating the share of Phantom FDI in Total FDI based on a model that does not include Luxembourg (green line); assuming that Phantom FDI in non-reporting economies constitutes 90 percent of Total FDI in offshore centers and that Phantom FDI is zero in other economies. Bottom panel: the figure shows inward Phantom FDI positions in 2017 for the 20 economies in the world with the largest such positions. For OECD economies reporting these statistics, the figure shows the reported numbers. For non-reporting economies, the figure shows our estimates (explained in the main text).
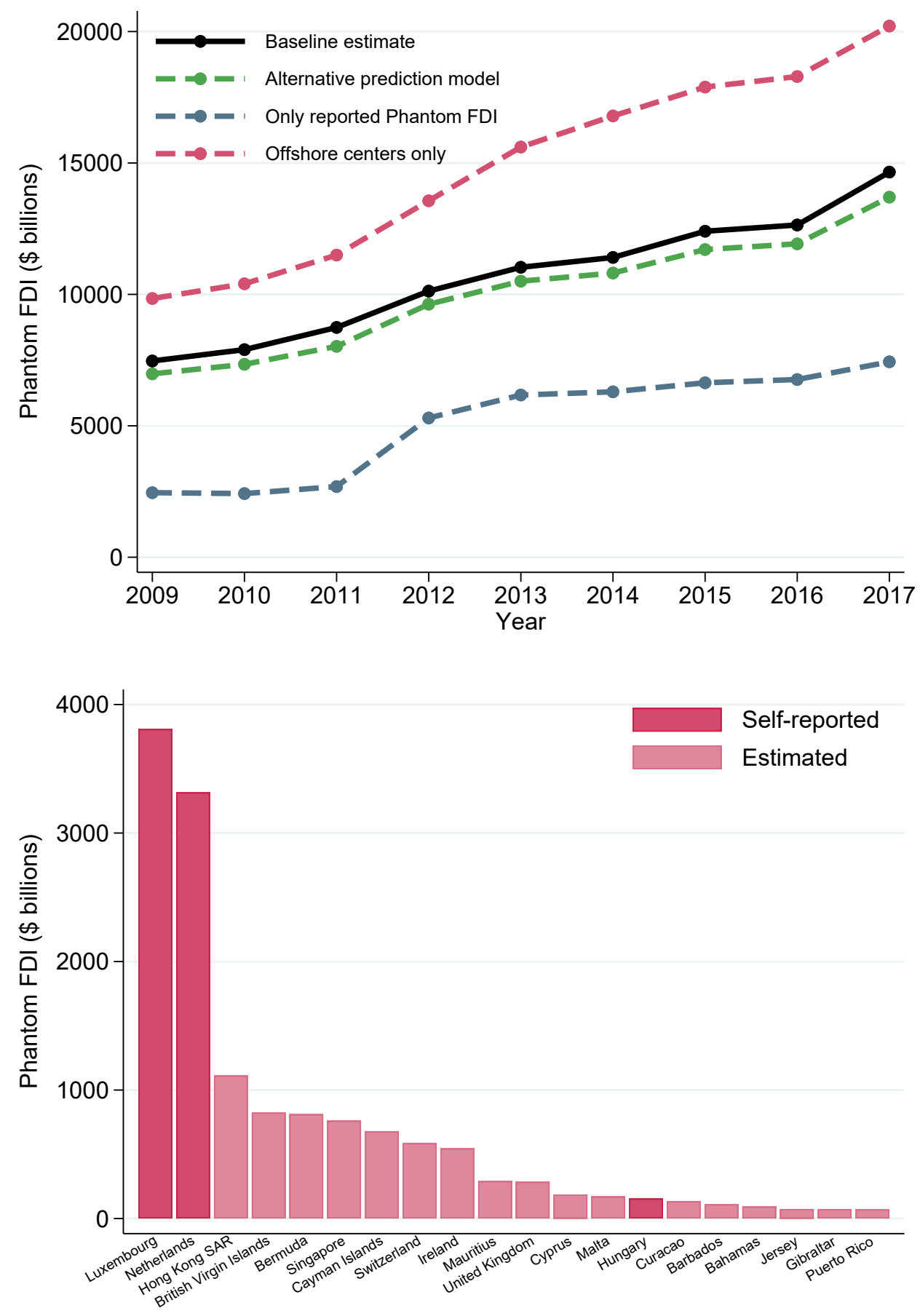
Figure 8 - Real FDI and ultimate ownership. Top panel: the figure shows inward Real FDI positions in 2017 for the 20 economies in the world with the largest such positions (blue bars). For OECD economies reporting these statistics, the figure shows the reported numbers. For non-reporting economies, the figure shows our estimates (explained in the main text). For each economy, the figure also shows the outward Real FDI position, i.e. sum of Real FDI in foreign economies ultimately owned by investors in the economy. Bottom Panel: the figure shows, for each of the 20 largest economies in the world with the largest outward FDI positions, the ratio between ultimately owned Real FDI and immediately owned Total FDI.
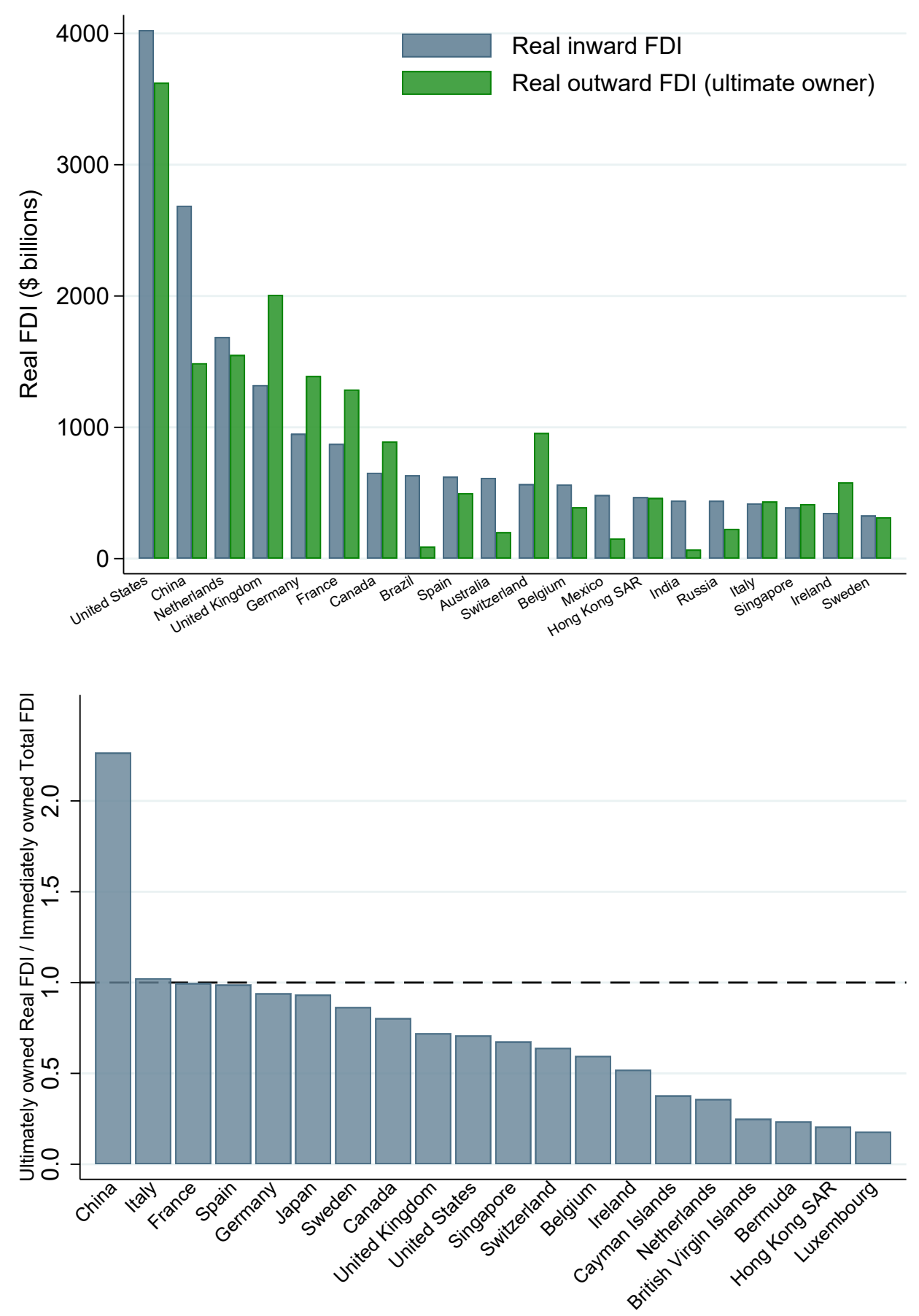
Figure 9 - Round-tripping and Real FDI links. Top panel: the figure shows the round-tripping factors (i.e. the share of inward Real FDI in economy $h$ ultimately owned by investors in economy $h$ ) for the 20 largest economies in the world (by GDP). Bottom panel: the figure also shows for each combination of the five largest economies in the world by GDP, United States (USA), China (CHN), Japan (JPN), Germany (DEU) and United Kingdom (GBR), the estimated Real FDI position capturing links between ultimate investors and real investments (blue bars) and the FDI position observed in standard FDI statistics (green bars).
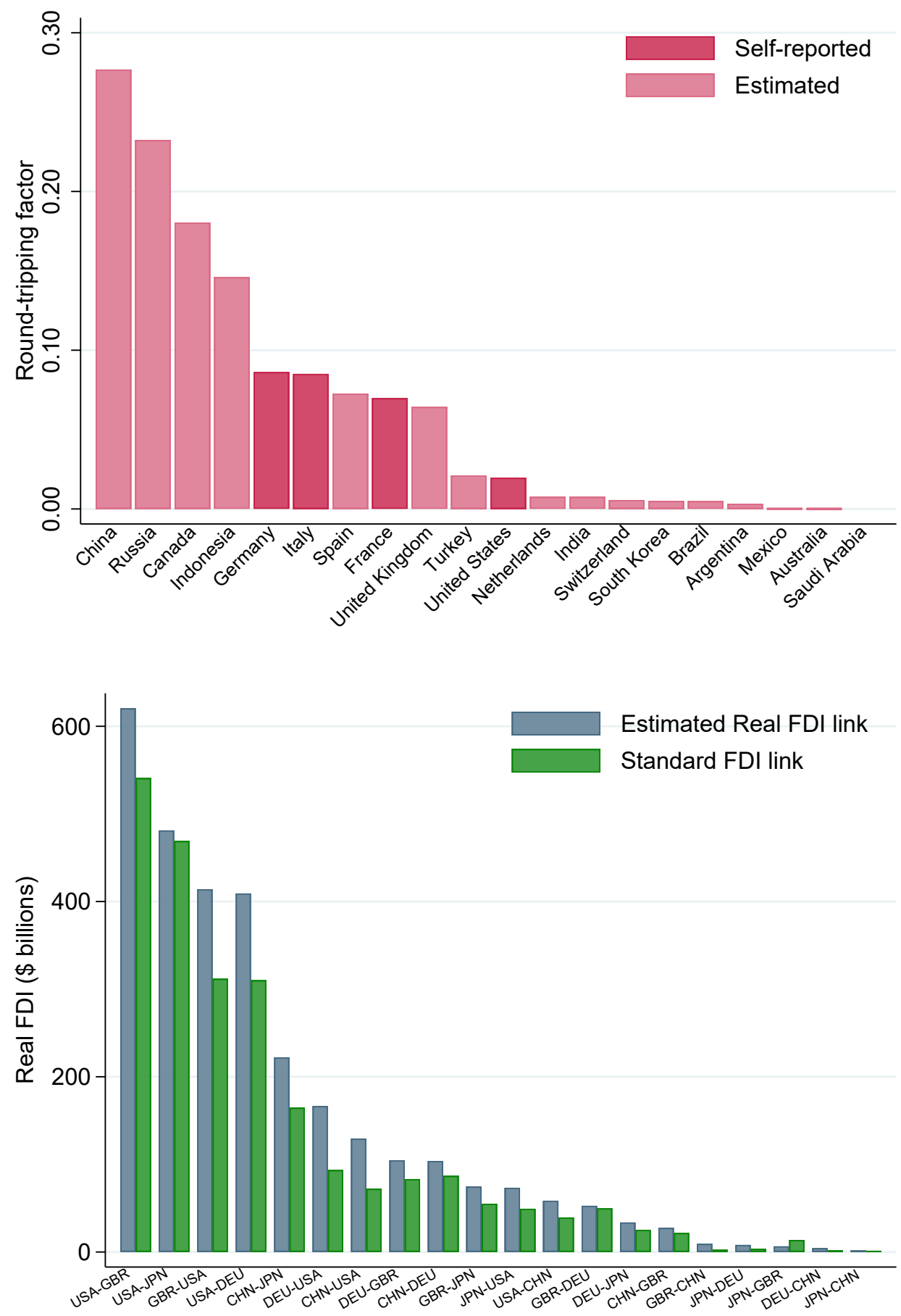
Figure 10 - Exposure to tax avoidance opportunities. Top panel: the figure shows for the 20 largest economies in the world (by GDP) the estimated share of outward Total FDI where the immediate investment is a foreign phantom corporation. Bottom Panel: the figure shows for the 20 largest economies in the world (by GDP) the estimated share of inward Total FDI where the immediate investor is a foreign phantom corporation.
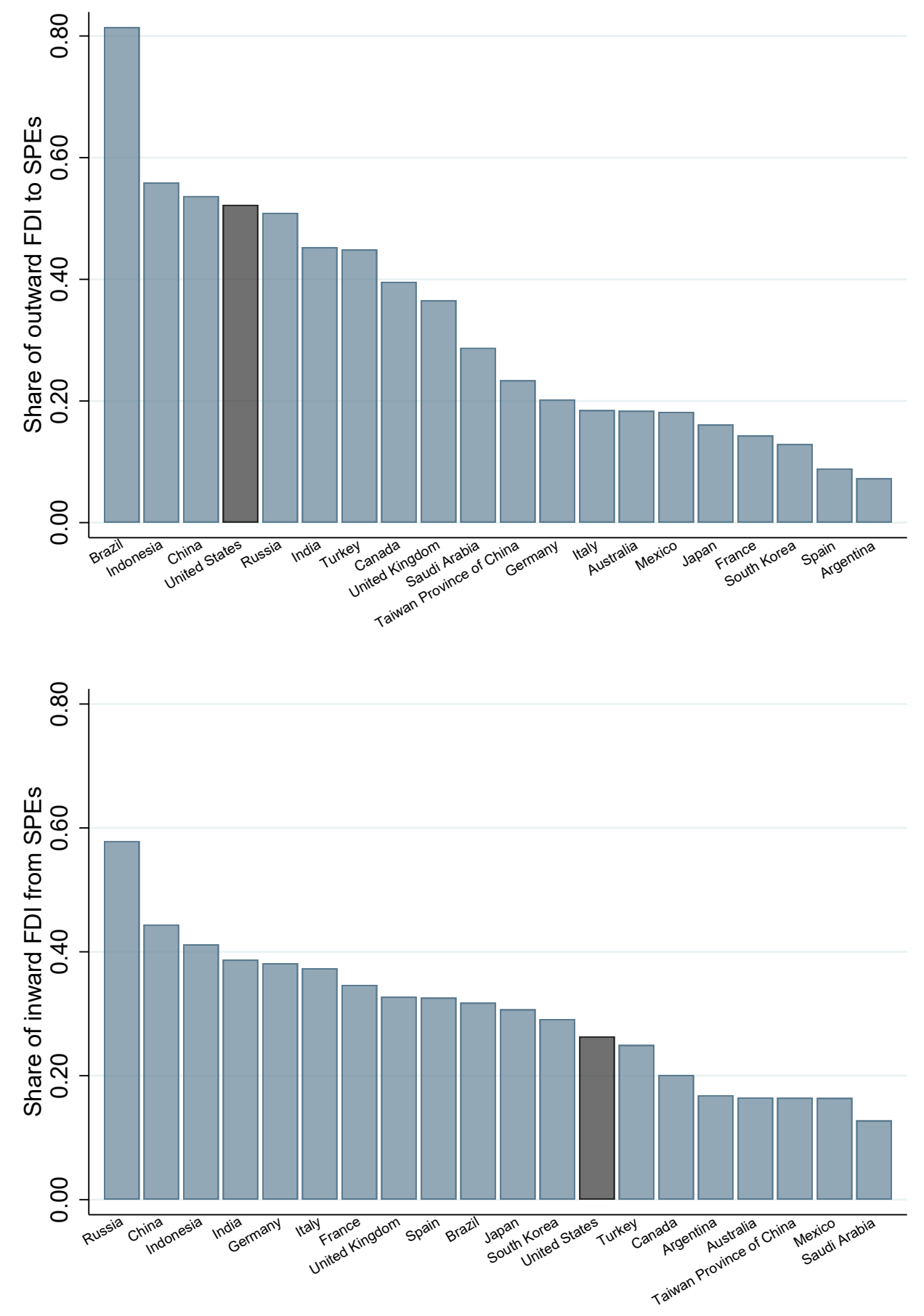
Table 1: Data sources and coverage (2016, FDI in \$billions). The table provides an overview of the three macro data sources and the coverage in terms of economies and FDI.

\begin{tabular}{|c|c|c|c|c|c|}
\hline \multicolumn{2}{|c|}{ IMF CDIS } & \multicolumn{2}{|c|}{ OECD FDI stats } & \multicolumn{2}{|c|}{ OECD FDI stats } \\
\hline Reporting economies & 111 & Reporting economies & 16 & Reporting economies & 12 \\
\hline Total inward FDI & 30,960 & Total inward FDI & 11,850 & Total inward FDI & 6,465 \\
\hline - allocated to IIE & 29,372 & - to SPEs ("Phantom FDI") & 6,761 & - allocated to UIEs & 6,384 \\
\hline - unallocated & 1,588 & - to non-SPEs ("Real FDI") & 5,089 & - unallocated & 81 \\
\hline
\end{tabular}


Table 2: Prediction model. The table shows the results from a pooled OLS regression for the period 2013-2017. The sample is the OECD countries reporting inward Total FDI positions into SPEs and nonSPEs separately. The dependent variable is Real FDI / Total FDI (in logs) where Real FDI is inward FDI into non-SPEs. The explanatory variables are: $F D I / G D P$ is the ratio of the inward Total FDI position to GDP; Trade is total foreign trade (imports plus exports) in goods.

\begin{tabular}{lccccc}
\hline \hline & $(1)$ & $(2)$ & $(3)$ & $(4)$ & $(5)$ \\
& \multicolumn{5}{c}{ Real FDI / Total FDI (in logs) } \\
FDI / GDP (in logs) & $-0.5044^{* * *}$ & $-0.5013^{* * *}$ & $-0.4884^{* * *}$ & $-0.5217^{* * *}$ & $-0.5059^{* * *}$ \\
& $(0.0357)$ & $(0.0346)$ & $(0.0339)$ & $(0.0338)$ & $(0.0355)$ \\
GDP (in logs) & & 0.0105 & & & 0.0094 \\
& & $(0.0274)$ & & & $(0.0227)$ \\
GDP / capita (in logs) & & & $-0.0934^{*}$ & & -0.0573 \\
& & & $(0.0474)$ & & $0.0598)$ \\
Trade / GDP (in logs) & & & & $0.1943^{* *}$ & 0.1581 \\
& & & & $(0.0820)$ & $0.0988)$ \\
Constant & $-0.4431^{* * *}$ & $-0.5743^{*}$ & 0.5389 & $-0.3948^{* * *}$ & 0.0815 \\
& $(0.0344)$ & $(0.3390)$ & $(0.4973)$ & $(0.0398)$ & $0.7091)$ \\
& & & & & 75 \\
Observations & 75 & 75 & 75 & 75 & 75 \\
R-squared & 0.8449 & 0.8452 & 0.8513 & 0.8561 & 0.8581 \\
\hline \hline
\end{tabular}


Table 3: Summary statistics (2017). The table provides an overview of the data sources ultimately used to construct the database. The first panel breaks down observations of inward Total FDI by immediate investor economy (IIE) into pairs where the value is reported to CDIS and pairs where the value is inferred from mirror data or based on our estimates. The second and third panels break down observations of inward Phantom FDI and inward Real FDI by immediate investor economy (IIE) into pairs where the value is reported to the OECD and pairs where the value is estimated from the prediction model. The fourth panel breaks down observations of inward Real FDI by ultimate investor economy (UIE) into pairs where the value is reported to the OECD and pairs where the value is estimated from the prediction model. In all cases, we report both the number of economy pairs and aggregate inward FDI (in \$billion).

\begin{tabular}{lcc}
\hline \hline & Pairs of economies & Inward FDI \\
\hline Inward Total FDI by IIE & $\mathbf{2 3 , 0 6 2}$ & $\mathbf{3 8 , 5 6 6}$ \\
- Reported to CDIS & 16,230 & 34,563 \\
- Mirror data & 6,693 & 3,435 \\
- Own estimate & 139 & 568 \\
& & \\
Inward Phantom FDI by IIE & $\mathbf{2 3 , 0 6 2}$ & $\mathbf{1 4 , 6 5 3}$ \\
- Reported to OECD & 2,393 & 7,436 \\
- Estimated & 20,669 & 7,217 \\
& & \\
Inward Real FDI by IIE & $\mathbf{2 3 , 0 6 2}$ & $\mathbf{2 3 , 9 1 2}$ \\
- Reported to OECD & 2,393 & 4,610 \\
- Estimated & 20,669 & 19,302 \\
& & \\
Inward Real FDI by UIE & $\mathbf{2 3 , 0 3 2}$ & $\mathbf{2 3 , 9 1 3}$ \\
- Reported to OECD & 1,598 & 5,220 \\
- Detailed Orbis & 625 & 4,296 \\
- Aggregate Orbis & 14,128 & 12,965 \\
- No adjustment & 6,681 & 1,432 \\
\hline \hline
\end{tabular}


Table 4: Gravity models. The table shows the results from pooled OLS regressions (Columns 1-4) and pooled Poisson regressions (Columns 4-8) for the period 2013-2017. The dependent variable is a measure of inward FDI: Total FDI (Columns 1 and 5); Phantom FDI (Columns 2 and 6); and Real FDI (Columns 3-4 and 7-8). The explanatory variables are: Host economy GDP is the GDP of the economy hosting the investment; Immediate investor economy GDP is the GDP of the economy of the immediate investor; Ultimate investor economy GDP is the GDP of the economy of the ultimate investor; Bilateral distance is the Euclidean distance between the economy of the investor and the economy of the investment; Contiguity is a dummy indicating whether the economy of the investment and the economy of the investor share a border; Common language is a dummy indicating whether the economy of the investment and the economy of the investor share an official language; Former colony is a dummy indicating whether the economy of the investment was formerly a colony of the economy of the investor or vice versa; Former same country is a dummy indicating whether the economy of the investment and the economy of the investor were formerly part of the same country. For the OECD economies reporting inward Total FDI positions into SPEs and non-SPEs separately, Phantom FDI is equal to the former and Real FDI to the latter. For other economies, Phantom FDI and Real FDI are estimated (explained above).

\begin{tabular}{|c|c|c|c|c|c|c|c|c|}
\hline & (1) & (2) & (3) & (4) & (5) & (6) & (7) & (8) \\
\hline & \multicolumn{4}{|c|}{ OLS pooled cross-section } & \multicolumn{4}{|c|}{ Poisson pooled cross-section } \\
\hline & All FDI & Phantom FDI & Real FDI & Real FDI & All FDI & Phantom FDI & Real FDI & Real FDI \\
\hline \multirow[t]{2}{*}{ Host economy GDP } & $0.524 * * *$ & $-0.119 * * *$ & $0.615^{* * *}$ & $0.665^{* * *}$ & $0.528 * * *$ & $0.144 * * *$ & $0.821^{* * *}$ & $0.813^{* * *}$ \\
\hline & $(0.00895)$ & $(0.0262)$ & $(0.00863)$ & $(0.00862)$ & $(4.40 \mathrm{e}-05)$ & $(6.58 \mathrm{e}-05)$ & $(6.45 e-05)$ & $(6.73 e-05)$ \\
\hline \multirow[t]{2}{*}{ Immediate investor economy GDP } & $0.652 * * *$ & $0.718 * * *$ & $0.667 * * *$ & & $0.561 * * *$ & $0.552 * * *$ & $0.575^{* * *}$ & \\
\hline & $(0.00835)$ & $(0.0218)$ & $(0.00806)$ & & $(4.66 \mathrm{e}-05)$ & (7.87e-05) & $(5.93 e-05)$ & \\
\hline \multirow[t]{2}{*}{ Ultimate investor economy GDP } & & & & $0.699 * * *$ & & & & $0.774 * * *$ \\
\hline & & & & $(0.00807)$ & & & & $(6.85 e-05)$ \\
\hline \multirow[t]{2}{*}{ Bilateral distance (in logs) } & $-0.824 * * *$ & $-0.728 * * *$ & $-0.877 * * *$ & $-0.857^{* * *}$ & $-0.678 * * *$ & $-0.785 * * *$ & $-0.662^{* * *}$ & $-0.623 * * *$ \\
\hline & $(0.0230)$ & $(0.0577)$ & $(0.0222)$ & $(0.0220)$ & $(8.98 \mathrm{e}-05)$ & $(0.000145)$ & $(0.000117)$ & $(0.000125)$ \\
\hline \multirow[t]{2}{*}{ Contiguity } & 0.153 & 0.437 & $0.191^{*}$ & $0.277^{* * *}$ & $-0.575^{* * *}$ & $-1.771^{* * *}$ & $-0.0999 * * *$ & $-0.156 * * *$ \\
\hline & $(0.107)$ & $(0.309)$ & $(0.103)$ & (0.101) & $(0.000318)$ & $(0.000668)$ & $(0.000372)$ & $(0.000408)$ \\
\hline \multirow[t]{2}{*}{ Common language (official) } & $1.979 * * *$ & $3.847 * * *$ & $1.900 * * *$ & $1.833^{* * *}$ & $1.122^{* * *}$ & $1.129 * * *$ & $0.967^{* * *}$ & $1.001^{* * *}$ \\
\hline & $(0.0552)$ & $(0.150)$ & $(0.0532)$ & $(0.0525)$ & $(0.000207)$ & $(0.000327)$ & $(0.000267)$ & $(0.000285)$ \\
\hline \multirow[t]{2}{*}{ Former colony } & $1.300 * * *$ & $1.238 * * *$ & $1.338^{* * *}$ & $1.291 * * *$ & $0.492 * * *$ & $0.464 * * *$ & $0.534 * * *$ & $0.498^{* * *}$ \\
\hline & $(0.113)$ & $(0.299)$ & (0.109) & $(0.107)$ & $(0.000287)$ & $(0.000500)$ & $(0.000352)$ & $(0.000363)$ \\
\hline \multirow[t]{2}{*}{ Formerly same country } & -0.102 & 0.147 & 0.0143 & -0.0187 & $1.321 * * *$ & $1.710^{* * *}$ & $1.178^{* * *}$ & $0.855^{* * *}$ \\
\hline & $(0.152)$ & $(0.410)$ & $(0.147)$ & $(0.144)$ & $(0.000327)$ & $(0.000565)$ & $(0.000395)$ & $(0.000499)$ \\
\hline \multirow[t]{2}{*}{ Constant } & $-4.116^{* * *}$ & $-1.208^{*}$ & $-5.167^{* * *}$ & $-6.293 * * *$ & $-0.533 * * *$ & $4.280 * * *$ & $-5.404 * * *$ & $-8.408^{* * *}$ \\
\hline & $(0.240)$ & $(0.650)$ & $(0.231)$ & $(0.229)$ & $(0.00106)$ & $(0.00171)$ & $(0.00146)$ & $(0.00161)$ \\
\hline Observations & 30,383 & 13,536 & 30,369 & 29,575 & 75,361 & 75,361 & 75,361 & 74,502 \\
\hline R-squared & 0.266 & 0.140 & 0.305 & 0.334 & - & - & - & - \\
\hline
\end{tabular}


Table 5: Exposure to tax avoidance opportunities. The table shows the results from OLS regressions for 2016. The dependent variable is the share of outward Total FDI where the immediate investment is a foreign phantom corporation (Columns 1-2) and the share of inward Total FDI where the immediate investor is a foreign phantom corporation (Columns 3-4). The explanatory variables are the headline corporate tax (Corp tax rate) and GDP per capita (GDP per cap).

\begin{tabular}{lcccc}
\hline \hline & $\begin{array}{c}(1) \\
\text { Share of outward } \\
\text { FDI to SPE }\end{array}$ & $\begin{array}{c}(3) \\
\text { Share of inward } \\
\text { FDI from SPE }\end{array}$ \\
\hline \multirow{3}{*}{ Corp tax rate } & & & & $(4)$ \\
& $0.00598^{* *}$ & $0.0381^{* *}$ & $-8.38 \mathrm{e}-05$ & $0.0203^{*}$ \\
GDP per cap (in logs) & $(0.00256)$ & $(0.0179)$ & $(0.00164)$ & $(0.0117)$ \\
& & 0.0725 & & 0.0559 \\
Corp tax rate GDP per cap (in logs) & & $(0.0520)$ & & $(0.0352)$ \\
& & $-0.00352^{*}$ & & $-0.00226^{*}$ \\
Constant & & $(0.00193)$ & & $(0.00128)$ \\
& $0.145^{* *}$ & -0.519 & $0.256^{* * *}$ & -0.249 \\
& $(0.0633)$ & $(0.479)$ & $(0.0412)$ & $(0.322)$ \\
Observations & & & & 123 \\
R-squared & 106 & 105 & 124 & 123 \\
\hline \hline
\end{tabular}




\section{Online Appendix}


Figure A1: Raw Orbis conversion factors. The figure shows the ratio of ultimately owned FDI to immediately owned FDI for the 50 largest economies in the world (by outward Real FDI) as observed in our Orbis dataset.

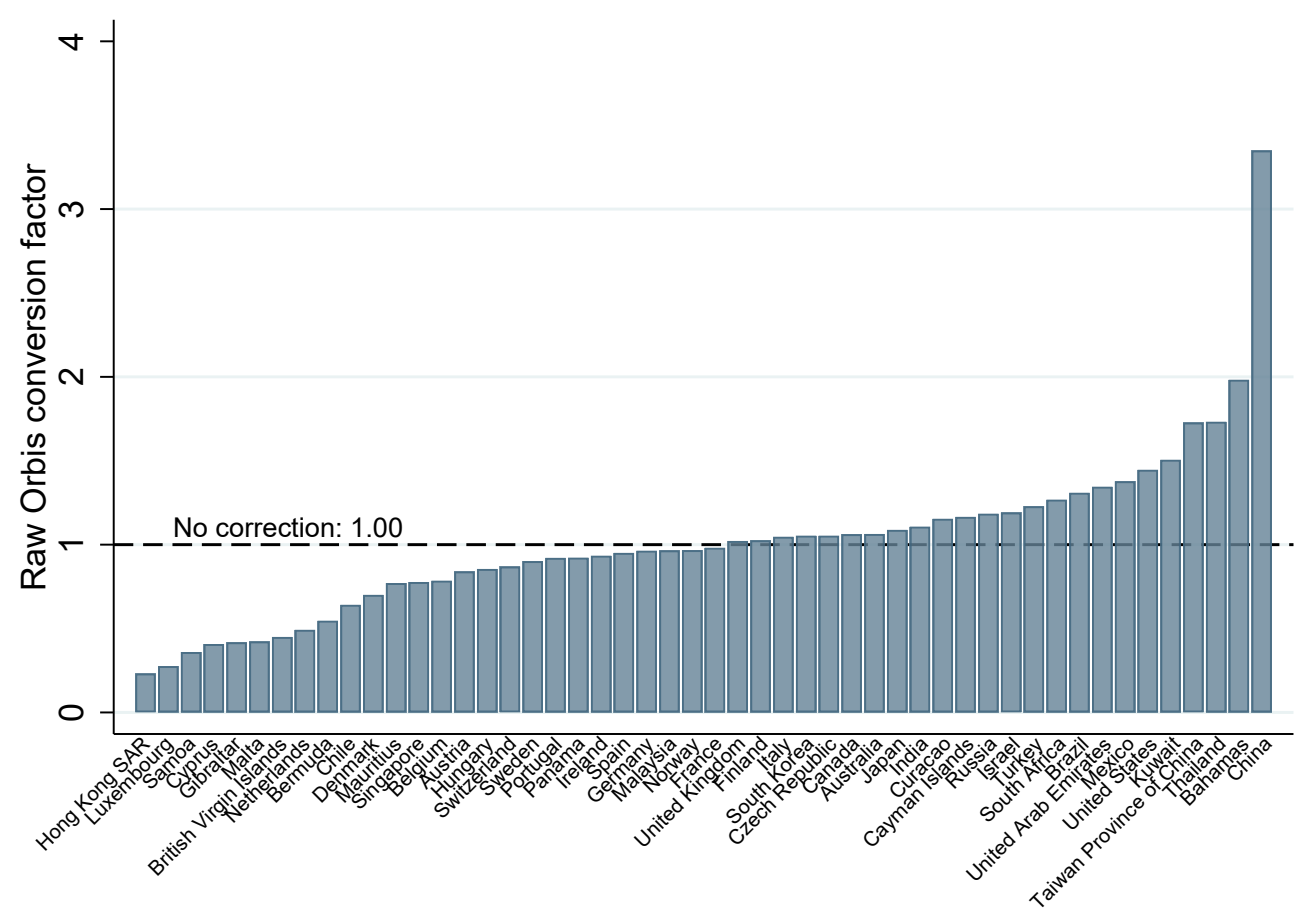


Figure A2: Raw Orbis round-tripping factors. The figure shows the ratio of inward Real FDI ultimately owned by investors in the economy itself to aggregate inward Real FDI in the economy for the 50 largest economies in the world (by inward Real FDI) as observed in our Orbis dataset.

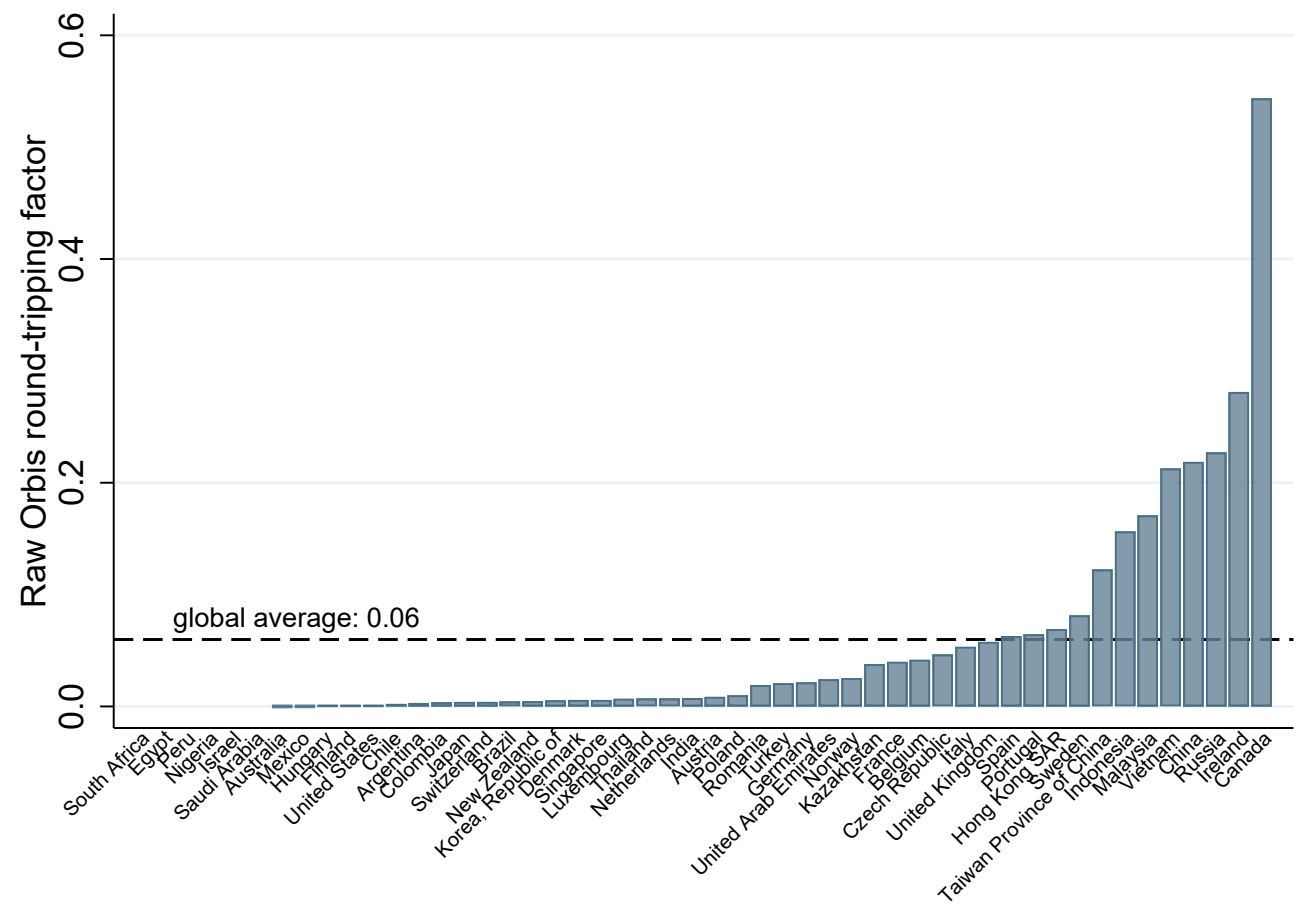


Figure A3: Testing uniform share of SPEs in inward FDI. Based on raw statistics from the group of reporting OECD countries, the figure plots the share of inward FDI into SPEs specific to each counterpart-economy (x-axis) against the share of inward FDI into SPEs in aggregate for the reporting country as a whole (y-axis). Notably for large counterpart economies, the observations are close to the 45-degree line.

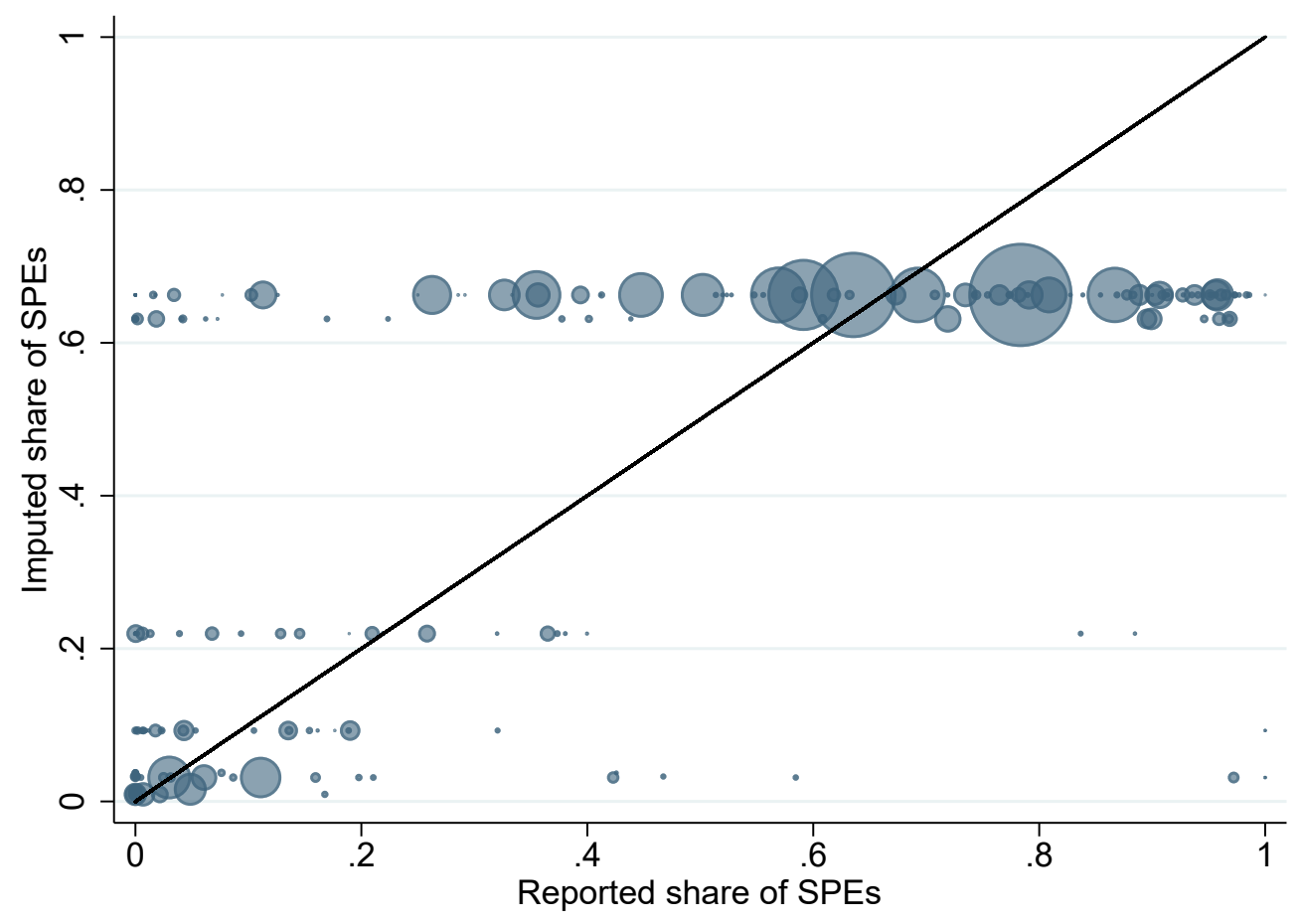


Figure A4: Testing uniform share of SPEs in outward FDI. Based on raw statistics from the group of reporting OECD countries, the figure plots the share of outward FDI into SPEs specific to each counterpart-economy (x-axis) against the share of outward FDI into SPEs in aggregate for the reporting country as a whole (y-axis). Notably for large counterpart economies, the observations are close to the 45-degree line.

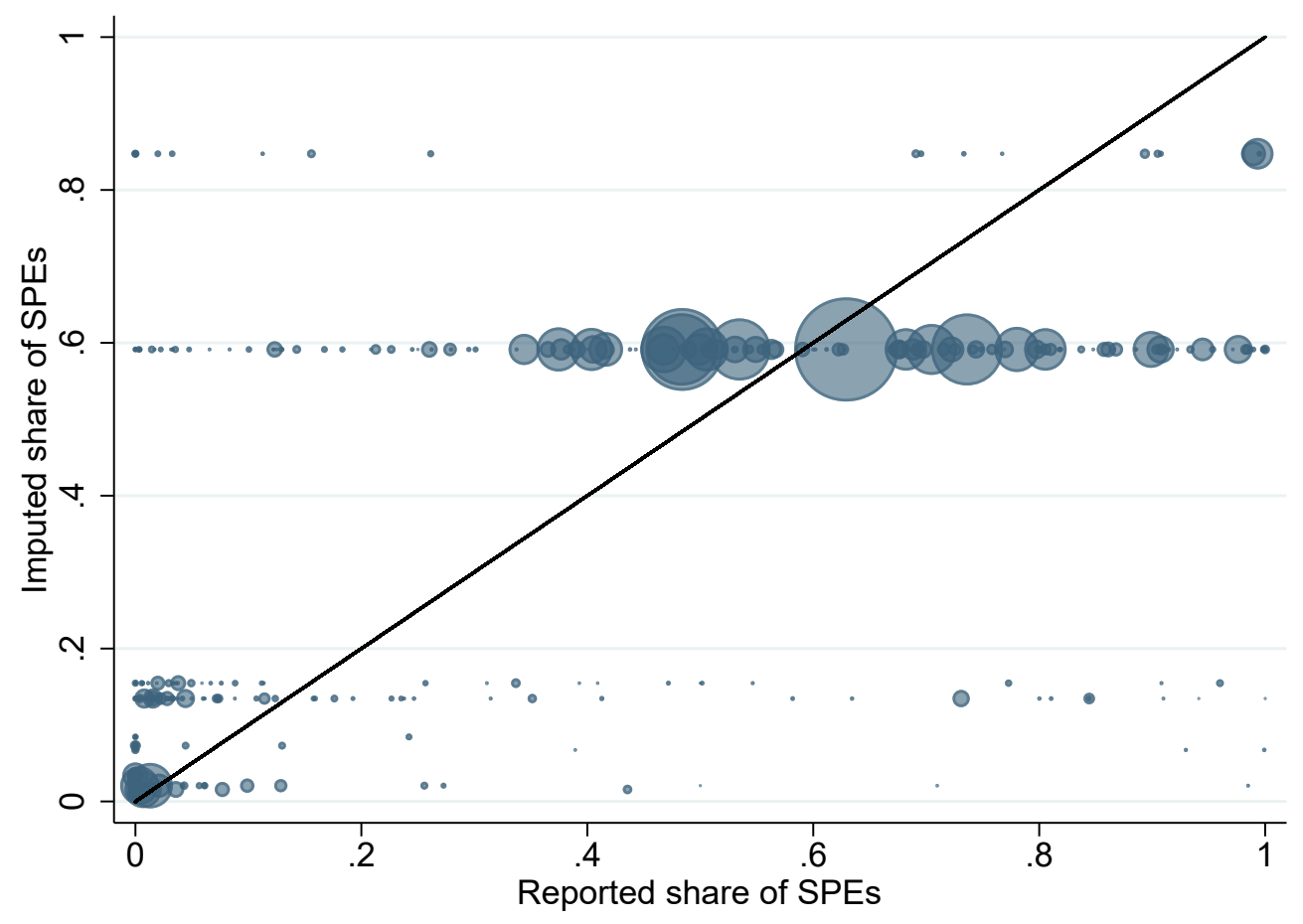

